Atmos. Chem. Phys., 17, 10515-10533, 2017

https://doi.org/10.5194/acp-17-10515-2017

(c) Author(s) 2017. This work is distributed under

the Creative Commons Attribution 3.0 License.

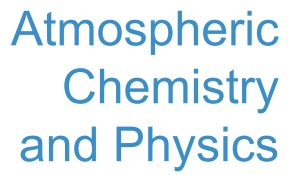

(c) (P)

\title{
Tagged tracer simulations of black carbon in the Arctic: transport, source contributions, and budget
}

\author{
Kohei Ikeda $^{1}$, Hiroshi Tanimoto ${ }^{1}$, Takafumi Sugita ${ }^{1}$, Hideharu Akiyoshi ${ }^{1}$, Yugo Kanaya ${ }^{2}$, Chunmao Zhu ${ }^{2}$, and \\ Fumikazu Taketani ${ }^{2}$ \\ ${ }^{1}$ National Institute for Environmental Studies, Tsukuba, 305-8506, Japan \\ ${ }^{2}$ Japan Agency for Marine-Earth Science and Technology, Yokohama, 236-0001, Japan \\ Correspondence to: Kohei Ikeda (ikeda.kohei@nies.go.jp) and Hiroshi Tanimoto (tanimoto@nies.go.jp)
}

Received: 14 March 2017 - Discussion started: 16 March 2017

Revised: 2 August 2017 - Accepted: 5 August 2017 - Published: 8 September 2017

\begin{abstract}
We implemented a tagged tracer method of black carbon (BC) into a global chemistry transport model, GEOSChem, examined the pathways and efficiency of long-range transport from a variety of anthropogenic and biomass burning emission sources to the Arctic, and quantified the source contributions of individual emissions. Firstly, we evaluated the simulated $\mathrm{BC}$ by comparing it with observations at the Arctic sites and examined the sensitivity of an aging parameterization and wet scavenging rate by ice clouds. For tagging $\mathrm{BC}$, we added $\mathrm{BC}$ tracers distinguished by source types (anthropogenic and biomass burning) and regions; the global domain was divided into 16 and 27 regions for anthropogenic and biomass burning emissions, respectively. Our simulations showed that $\mathrm{BC}$ emitted from Europe and Russia was transported to the Arctic mainly in the lower troposphere during winter and spring. In particular, BC transported from Russia was widely spread over the Arctic in winter and spring, leading to a dominant contribution of $62 \%$ to the Arctic BC near the surface as the annual mean. In contrast, $\mathrm{BC}$ emitted from East Asia was found to be transported in the middle troposphere into the Arctic mainly over the Sea of Okhotsk and eastern Siberia during winter and spring. We identified an important "window" area, which allowed a strong incoming of East Asian BC to the Arctic (130$180^{\circ} \mathrm{E}$ and $3-8 \mathrm{~km}$ of altitude at $66^{\circ} \mathrm{N}$ ). The model demonstrated that the contribution from East Asia to the Arctic had a maximum at about $5 \mathrm{~km}$ of altitude due to uplifting during long-range transport in early spring. The efficiency of BC transport from East Asia to the Arctic was lower than that from other large source regions such as Europe, Russia, and North America. However, the East Asian contribution was
\end{abstract}

the most important for $\mathrm{BC}$ in the middle troposphere $(41 \%)$ and the $\mathrm{BC}$ burden over the Arctic (27\%) because of the large emissions from this region. These results suggested that the main sources of Arctic BC differed with altitude. The contribution of all the anthropogenic sources to Arctic BC concentrations near the surface was dominant $(90 \%)$ on an annual basis. The contributions of biomass burning in boreal regions (Siberia, Alaska, and Canada) to the annual total BC deposition onto the Arctic were estimated to be $12-15 \%$, which became the maximum during summer.

\section{Introduction}

Arctic temperatures have increased more rapidly than the global average during recent decades (Shindell and Faluvegi, 2009). While increases in long-lived greenhouse gases certainly play a leading role in Arctic warming, short-lived climate pollutants (SLCPs), such as aerosols and tropospheric ozone, also have a substantial influence on Arctic climate (Shindell, 2007; Quinn et al., 2008; Sand et al., 2016). Black carbon (BC) has particularly attracted interest due to its large influences on radiative forcing in the Arctic (AMAP, 2015). $\mathrm{BC}$ causes a heating in the atmosphere by absorbing solar radiation, which is more efficient in the Arctic because of the high surface albedo of snow and ice (Quinn et al., 2007). In addition, the deposition of $\mathrm{BC}$ on snow and ice reduces the surface albedo and results in faster-melting snow and ice sheets in the Arctic (Hansen and Nazarenko, 2004; Flanner et al., 2007). Enhanced aerosol concentrations can also increase cloud longwave emissivity and lead to surface warm- 
ing in the Arctic (Lubin and Vogelmann, 2006; Garrett and Zhao, 2006). In the Arctic, air pollution and climate change are strongly linked, and reductions in the concentrations of SLCPs could contribute to mitigating Arctic warming (Quinn et al., 2008; Arnold et al., 2016).

Aerosols in the Arctic show a distinct seasonal variation with a maximum during winter and early spring and a minimum in summer (Barrie, 1986). Arctic air pollution, including high concentrations of aerosols and reactive gases (socalled Arctic haze), primarily originates from anthropogenic pollutants transported from the northern midlatitudes (Law and Stohl, 2007). The seasonal variation in Arctic air pollution is caused by the enhanced transport of pollutants from the midlatitudes, inefficient removal processes in winter and spring, and increased wet scavenging during summer (Law and Stohl, 2007; Garrett et al., 2011).

Previous studies using chemical transport models (CTMs) and chemical climate models (CCMs) revealed that these models had difficulty in reproducing the seasonal variations in aerosols in the Arctic (Shindell et al., 2008; Koch et al., 2009; Lee et al., 2013). Most models underestimated the concentration levels of $\mathrm{BC}$ in the peak season, and the modelto-model differences were also quite large (Shindell et al., 2008). This is caused by uncertainties in the model treatments of transformation from hydrophobic to hydrophilic $\mathrm{BC}$ and removal processes during long-range transport from source regions to the Arctic. The seasonal variation in simulated $\mathrm{BC}$ in the Arctic is particularly sensitive to parameterizations of BC aging (Liu et al., 2011; Lund and Berntsen, 2012; He et al., 2016) and wet scavenging processes (Liu et al., 2011; Bourgeois and Bey, 2011; Browse et al., 2012; Qi et al., 2017a, b). This is consistent with observational analyses by Garrett et al. (2011) who suggested that the wet scavenging process was dominant in determining the seasonal variations in light absorption and light-scattering aerosols in the Arctic. Although a recent model intercomparison study indicated that the model performance of the BC simulations in the Arctic has improved, the seasonal amplitude at the surface was too weak and the BC concentration levels at the surface sites were still underestimated in the Arctic haze season in many state-of-the-science models (Eckhardt et al., 2015). Mahmood et al. (2016) pointed out that convective wet deposition outside the Arctic influenced vertical distribution and seasonal variations in $\mathrm{BC}$ in the Arctic by analyzing the same models used by Eckhardt et al. (2015). These difficulties in the model simulation of Arctic BC are key uncertainties in calculating the source contributions from important emission sources in the northern midlatitudes and high latitudes.

In addition to the model representations of $\mathrm{BC}$ aging and removal processes, it has been recently reported that missing emission sources in the high latitudes significantly contribute to the underestimation of simulated BC in the Arctic (Stohl et al., 2013; Huang et al., 2015). Stohl et al. (2013) estimated that gas flaring in Russia that is not treated in most inventories contributes $42 \%$ to the annual mean BC concen- trations near the surface in the Arctic. Huang et al. (2015) also showed that newly developed BC emissions for Russia, which includes emissions from gas flaring, improved the model biases of $\mathrm{BC}$ at the surface sites in the Arctic.

Previous efforts to investigate the source regions of $\mathrm{BC}$ in the Arctic were made using a Lagrangian trajectory model (Stohl, 2006; Hirdman et al., 2010) and chemical transport models (Koch and Hansen, 2005; Shindell et al., 2008; Huang et al., 2010; Bourgeois and Bey, 2011; Wang et al., 2011, 2014; Sharma et al., 2013; Qi et al., 2017c). These previous studies revealed that major BC sources transported to the Arctic were anthropogenic emissions in Europe, Russia, Asia, and North America. However, the relative importance among these source regions is still rather uncertain or even contradictory because the estimated contributions to Arctic BC vary in earlier studies (Wang et al., 2014). For instance, while Lagrangian trajectory model analyses suggested that northern Eurasia was the major source of BC near the surface in the Arctic (Stohl, 2006; Hirdman et al., 2010), Koch and Hansen (2005) estimated that the degree of the contribution from South and East Asia was similar to that from Europe and Russia during winter and spring. In the middle troposphere over the Arctic, some studies suggested that the contributions from Europe and/or Russia were larger than or comparable to those from Asia (Shindell et al., 2008; Huang et al., 2010; Sharma et al., 2013), but other studies indicated that the contribution from Asia was dominant (Koch and Hansen, 2005; Wang et al., 2011, 2014). This highlights the need for and importance of a mechanistic understanding of transport pathways and wet removal processes during long-range transport from individual major source regions to the Arctic.

Previous studies have also reported that biomass burning emissions from boreal forests in Siberia and North America and agricultural fires in Europe have substantial influences on Arctic BC, especially from late spring to summer (Stohl et al., 2006, 2007; Warneke et al., 2010; Matsui et al., 2011). Stohl (2006) suggested that the contribution from Siberian forest fires to the Arctic was greater than that from anthropogenic sources during summer. Matsui et al. (2011) indicated that the biomass burning emissions in Russia had the most important contributions of $\mathrm{BC}$ in the North American Arctic in spring 2008, when severe fires occurred in Siberia. Emissions from fires in boreal forests may increase under the future warm climate (Stocks et al., 1998). Thus, it is important to investigate the contribution from biomass burning emissions at relatively high latitudes to Arctic BC.

In this study, we investigated the long-range transport of $\mathrm{BC}$ from various source regions and origins to the Arctic using a global chemical transport model, GEOS-Chem, with a tagged tracer simulation for the past 5 years (2007-2011). The tagged tracer method was used to analyze detailed transport pathways and transport efficiencies of BC from individual sources to the Arctic. We identified an important geographic region where the inflow of $\mathrm{BC}$ from major source re- 
gions into the Arctic occurred. This analysis also provides us with an interpretation of the seasonal variation in Arctic BC and useful diagnostics of the model performance to understand the possible causes of model biases. We also quantitatively estimated the contributions of emissions from various sources to BC concentrations and depositions in the Arctic region.

\section{Model description}

We used GEOS-Chem version 9-02 as a global chemical transport model (Bey et al., 2001). GEOS-Chem is driven by assimilated meteorological data from the Goddard Earth Observing System (GEOS-5) provided by the NASA Global Modeling and Assimilation Office (GMAO). The model used a horizontal resolution of $2^{\circ} \times 2.5^{\circ}$ with 47 vertical layers from the surface to $10 \mathrm{hPa}$. The dry deposition process in GEOS-Chem adopts a standard resistance-in-series scheme as implemented by Wang et al. (1998). Over snow and ice, $\mathrm{BC}$ dry deposition velocity is set to $0.03 \mathrm{~cm}^{-1}$ to improve aerosol concentrations at the Arctic surface sites as described in Fisher et al. (2011) and Wang et al. (2011).

\subsection{Emission inventories}

For anthropogenic emissions of BC, GEOS-Chem originally used an inventory from Bond et al. (2007) for 2000. Wang et al. (2011) indicated that emissions in Asia and Russia were required to be doubled to match them with observed $\mathrm{BC}$ over the Arctic. This doubling was done to account for the emission increases since 2000 in Russia and China (Wang et al., 2011). In this study, we adopted the BC emissions of HTAP v2.2 (Janssens-Maenhout et al., 2015), which were developed for the experiments of HTAP phase 2 for anthropogenic emissions. The target year of HTAP v2.2 was 2010, and global annual emissions were estimated to be $5.5 \mathrm{Tg} \mathrm{yr}^{-1}$, which was about $22 \%$ higher than those in Bond et al. (2007; $4.5 \mathrm{Tg} \mathrm{yr}^{-1}$ ). On a regional basis, the emissions from China were $40 \%$ higher than those in Bond et al. (2007), and the emissions from Europe and North America were 34 and $11 \%$ lower than those in Bond et al. (2007), respectively. As argued in recent studies, BC emissions from Russia may be underestimated due to missing sources, such as gas flaring, and have a significant impact on Arctic BC (Stohl et al., 2013; Huang et al., 2015). Annual BC emissions in Russia were estimated to be $224 \mathrm{Gg} \mathrm{yr}^{-1}$ in Huang et al. (2015), which was about 2.5 times larger than those of HTAP v2.2. Our preliminary simulations found that the model result replacing HTAP v2.2 emissions in Russia with the inventory of Huang et al. (2015) improved the reproducibility of the observed BC concentrations at the Arctic sites (see the Supplement, Fig. S1), and thus we used this emission data set as the anthropogenic BC emissions for Russia. For biomass burning emissions, we used GFED (Global Fire Emissions Database) v3.1 with $0.5^{\circ} \times 0.5^{\circ}$ of spatial resolution and daily temporal resolution (van der Werf et al., 2010). In GFED v3.1 the BC emissions from biomass burning were globally estimated to be $1.9 \mathrm{Tg} \mathrm{yr}^{-1}$ averaged for 2007-2011.

\subsection{BC aging and wet scavenging schemes}

In the standard GEOS-Chem model, $80 \%$ of BC is initially emitted as hydrophobic $\mathrm{BC}$ and then converted to hydrophilic BC with a constant e-folding time of 1.15 day (Park et al., 2005). However, it is unknown whether it is appropriate to adopt a constant value for the entire atmosphere. Because this value was estimated from observations of continental outflow near the source regions in the midlatitudes (Park et al., 2005), it may be overestimated, especially in remote regions, including the high latitudes. In this study, we implemented a parameterization of BC aging developed by Liu et al. (2011) into GEOS-Chem and tested this impact on BC concentrations over the Arctic. This parameterization derives a timescale of $\mathrm{BC}$ aging based on the number concentration of $\mathrm{OH}$ radical (Liu et al., 2011). In remote areas, including the high latitudes, the aging time is expected to be longer than in the midlatitudes near the source regions, resulting in an increase in BC concentrations. Liu et al. (2011) showed that the simulated seasonal variations at Arctic sites were improved by implementing this parameterization due to the increases in the $\mathrm{BC}$ concentrations during winter and spring.

Wet scavenging processes are also important to simulate $\mathrm{BC}$ in the Arctic region. The wet scavenging scheme for aerosols in GEOS-Chem is originally described by Liu et al. (2001). Wang et al. (2011) implemented several improvements for wet scavenging to distinguish between liquid and ice clouds for in-cloud scavenging (rainout) by comparing it with ARCTAS aircraft measurements over the Arctic. In liquid clouds ( $T \geq 258 \mathrm{~K}$ ), hydrophilic aerosols are assumed to be incorporated in the cloud droplets. In the case of ice clouds $(T<258 \mathrm{~K})$, the model assumes that hydrophobic BC can serve as ice nuclei. However, the scavenging of BC by ice clouds is highly uncertain (Wang et al., 2011). The assumption of $100 \%$ of hydrophobic BC can lead to an overestimation of $\mathrm{BC}$ scavenging in ice clouds. We conducted a sensitivity simulation in which the scavenging rate of hydrophobic BC was reduced to $5 \%$ of water-soluble aerosols for liquid clouds by following earlier model studies (Bourgeois and Bey, 2011). We found that the reduced scavenging rate by ice clouds improved the model reproducibility of BC at the Arctic sites in winter and spring, as will be discussed in detail below.

\subsection{BC tracer tagging by sources and regions}

In the tagged tracer simulations, we distinguished the $\mathrm{BC}$ tracers by source types (i.e., anthropogenic and biomass burning) and regions. The horizontal definitions of source regions are shown in Fig. 1. For the tagging of anthropogenic 


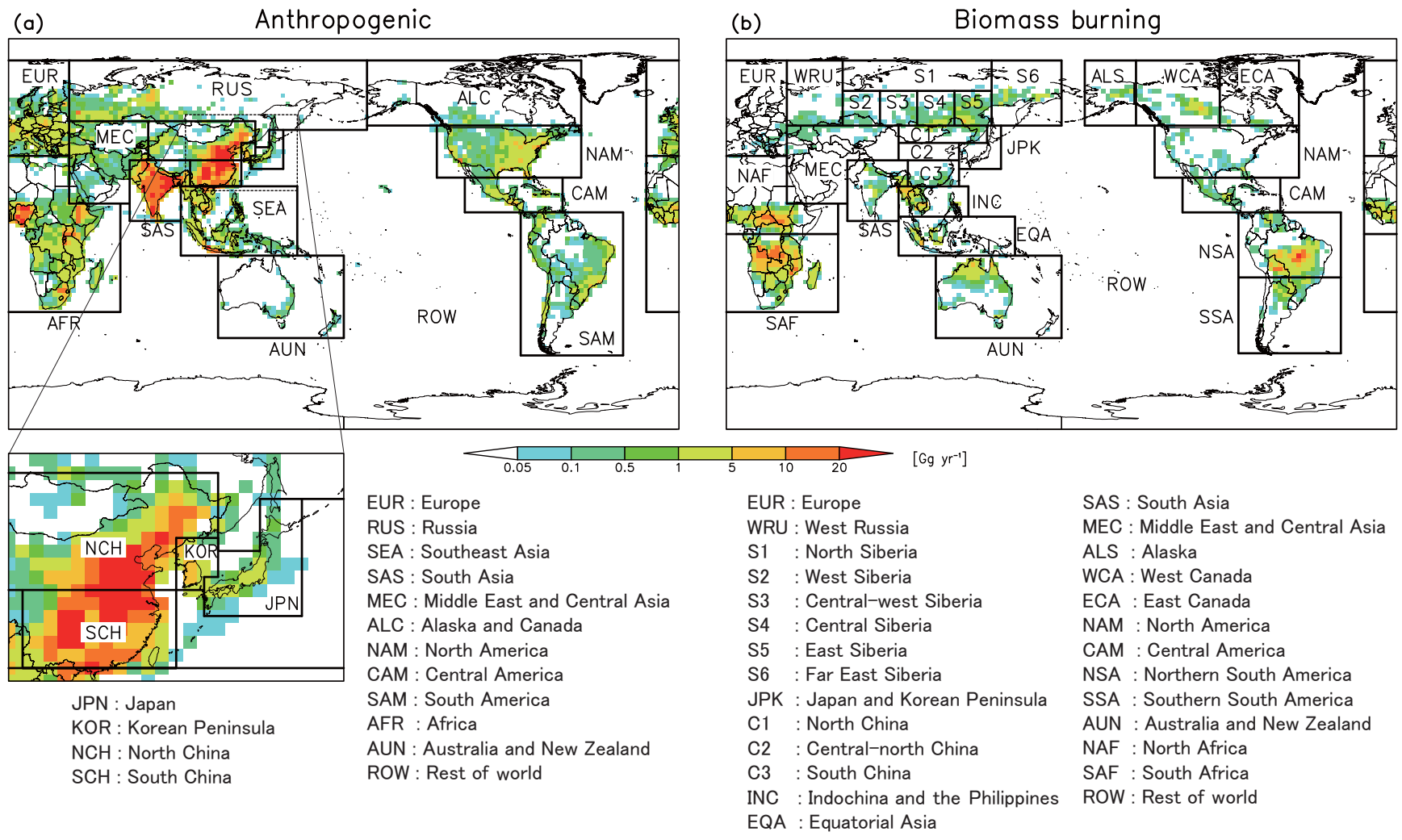

Figure 1. Annual emissions of BC from (a) anthropogenic and (b) biomass burning sources for the year 2010 and 2007-2011, respectively, and source regions for $\mathrm{BC}$ tracer tagging.

(AN) BC, we divided the global domain into 16 regions (Fig. 1a). We separated Europe, Russia, Asia, and North America to examine transport patterns and contributions to the Arctic from the major source regions. Asia was separated into three regions (i.e., East Asia, Southeast Asia, and South Asia). East Asia was further divided into four regions: Japan, the Korean Peninsula, North China, and South China. For biomass burning (BB) emissions, we separated the model domain into 27 regions (Fig. 1b). For boreal forests, Siberia was separated into six regions based on vegetation types, and North America was divided into Alaska, West Canada, and East Canada in addition to the United States.

We performed the tagged simulation for 5 years from 2007 to 2011 after a model spin-up of 6 months. The model simulation was conducted as an offline aerosol simulation and used an improved wet scavenging and aging process. The monthly average $\mathrm{OH}$ distributions for the calculation of $\mathrm{BC}$ aging time were stored by the full-chemistry simulation for each year.

To examine the role of wet removal during transport for each tagged $\mathrm{BC}$ tracer, we estimated the wet scavenging ratio of $\mathrm{BC}$. Using the wet scavenging ratio, we discuss the differences in transport efficiency among source regions and the roles of wet removal processes for the seasonal variations in $\mathrm{BC}$ concentrations. We conducted an additional simulation in which the wet scavenging processes were off, and thus BC was removed from the atmosphere only by dry deposition at the surface. The wet scavenging ratio of each $\mathrm{BC}$ tracer was estimated as follows:

wet scavenging ratio $(\%)=\left(C_{\text {wetoff }}-C_{\mathrm{ctl}}\right) / C_{\mathrm{ctl}} \times 100$,

where $C_{\mathrm{ctl}}$ and $C_{\text {wetoff }}$ are 6-hourly BC concentrations of the control run and the simulation in which the wet removal processes are off, respectively.

\section{Results and discussion}

\subsection{Model-observation comparison}

The BC mass concentrations simulated by GEOS-Chem were compared with measurements of equivalent BC (EBC) converted from aerosol light absorption at four Arctic sites: Barrow, Alaska (156.6 $\mathrm{W}, 71.3^{\circ} \mathrm{N} ; 11 \mathrm{~m}$ a.s.1.), Alert, Canada $\left(62.3^{\circ} \mathrm{W}, 82.5^{\circ} \mathrm{N} ; 210 \mathrm{~m}\right.$ a.s.1.), Zeppelin, Norway $\left(11.9^{\circ} \mathrm{E}, 78.9^{\circ} \mathrm{N} ; 478 \mathrm{ma.s.1}\right)$, and Tiksi, Russia $\left(128.9^{\circ} \mathrm{E}\right.$, $71.6^{\circ} \mathrm{N} ; 8 \mathrm{~m}$ a.s.l.). Aerosol light absorption is observed by particle soot absorption photometers (PSAPs) at Barrow, Alert, and Zeppelin and by an Aethalometer at Tiksi. The measurement data at the Arctic sites were obtained from the EMEP and WDCA database (http://ebas.nilu.no). EBC is 

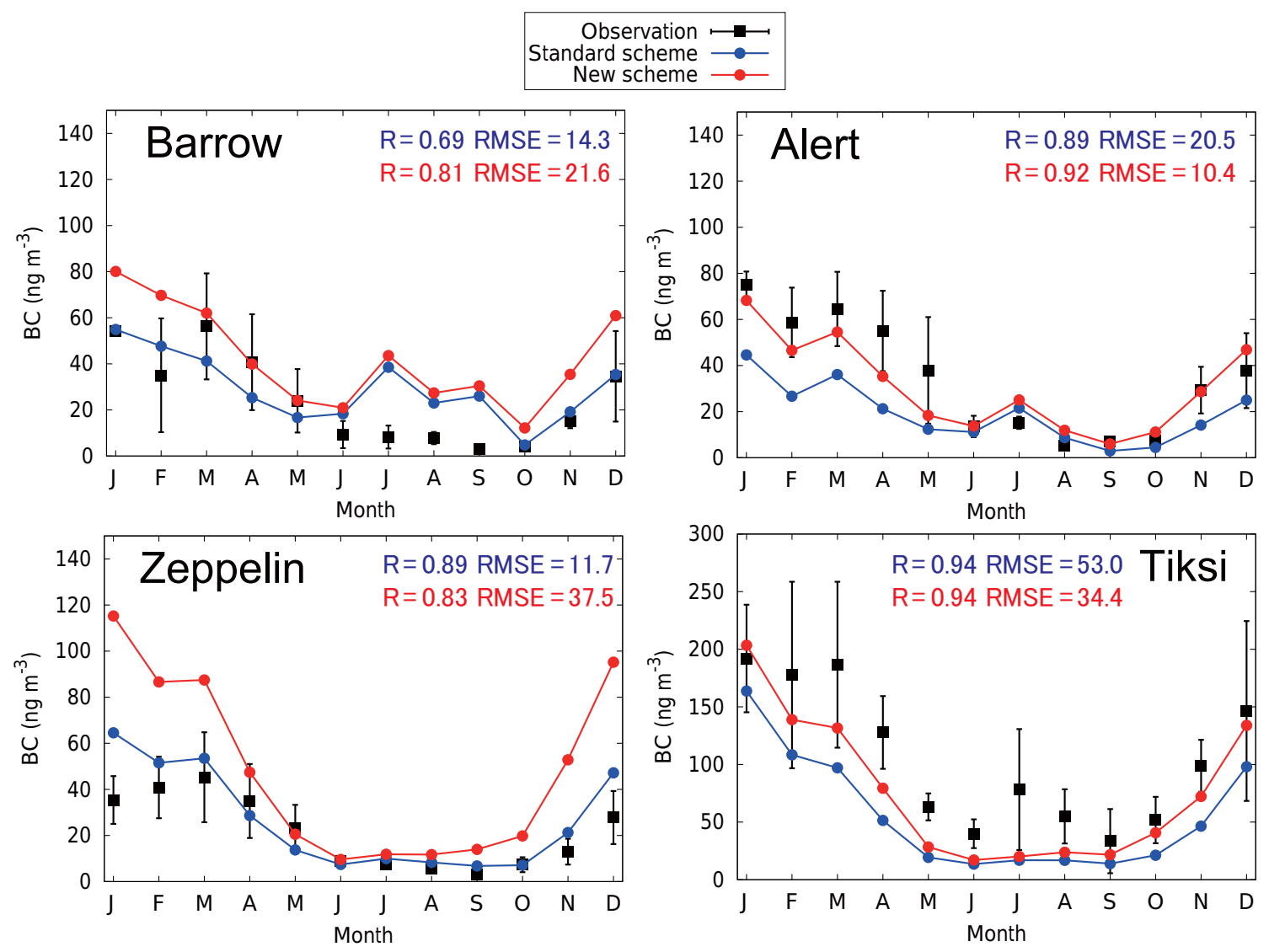

Figure 2. Observed (black squares) and modeled (blue solid line for standard scheme and red solid line for new scheme) seasonal variations in BC mass concentrations at the Arctic sites. The plots are monthly means and the error bars are standard deviations of interannual variations. Measurements are averaged for 2007-2011 at Barrow, Alert and Zeppelin, and for 2010-2014 at Tiksi. R and RMSE indicate correlation coefficient and root mean square error, respectively. The unit of RMSE is $\mathrm{ng} \mathrm{m}^{-3}$.

calculated from the particle light absorption coefficient with an assumption of a mass absorption efficiency. In this study, the measured light absorption coefficients with PSAPs have been converted to EBC mass concentrations using the mass absorption efficiency of $10 \mathrm{~m}^{2} \mathrm{~g}^{-1}$ (Bond and Bergstrom, 2006). The conversion to EBC was internally performed by the Aethalometer for Tiksi.

Figure 2 shows the seasonal variations in $\mathrm{BC}$ concentrations simulated with the GEOS-Chem standard scheme and our new scheme in comparison to the observations at the Arctic sites. The observed seasonal variations in $\mathrm{BC}$ at the Arctic surface sites show a maximum during winter and early spring (i.e., Arctic haze season) and a minimum in summer. This observed seasonal feature was relatively well simulated with the standard scheme at the semi-quantitative level (the correlation coefficients between the modeled and the observed BC $(R)$ were $0.69-0.94)$. The new scheme yielded an increase in $\mathrm{BC}$ concentrations with maximum effects in winter at all four Arctic sites. This is consistent with the results of Liu et al. (2011) and Bourgeois and Bey (2011). By introducing the aging parameterization of Liu et al. (2011), the lifetime of $\mathrm{BC}$ was increased due to a slower timescale of aging in the high latitudes. Reducing the wet scavenging ratio by ice clouds also increased the lifetime of $\mathrm{BC}$ in the cold season. The sensitivities by changing these parameterizations were largest in winter because wet removal by ice clouds was the most important in this season and the aging timescale, which depends on $\mathrm{OH}$ number concentrations, also became longer than other seasons. The standard scheme underestimated observed $\mathrm{BC}$ in winter and spring at Alert and Tiksi. The model negative biases were reduced by the new scheme in these seasons, and $R$ values were improved from 0.89 to 0.92 at Alert and from 0.935 to 0.944 at Tiksi (Fig. 2). At Barrow, while the new simulation improved the negative biases in spring, the observed concentrations were overestimated during winter. As a result, the correlation coefficient was increased from 0.69 to 0.81 , but root mean square error (RMSE) was not improved by the new scheme at Barrow. Whilst there was an improvement at Alert and Tiksi, the observations at Zeppelin showed reasonably good agreement with the standard simulation $(R=0.89)$ rather than the new simulation $(R=0.83)$. The new scheme yielded nearly double BC concentrations 
in winter, while the observed $\mathrm{BC}$ concentrations were somewhat lower than those at the other three sites. The sensitivities of aging and wet removal by ice cloud processes at Zeppelin were larger than those at Barrow and Alert, leading to the overestimation of the new scheme in winter and spring. Previous model studies also showed similar tendencies with larger BC concentrations in the European Arctic (i.e., at Zeppelin) than those in the North American Arctic (i.e., at Barrow and Alert; Sharma et al., 2013; Stohl et al., 2013; AMAP, 2015). It should be noted that the mass absorption efficiency used for the conversion from the particle absorption coefficients to the EBC concentrations has an uncertainty of at least a factor of 2 (AMAP, 2015).

We further compared the vertical profiles of BC concentrations over the Arctic with the observations made during the Arctic Research of the Composition of the Troposphere from Aircraft and Satellites (ARCTAS) campaign in April 2008 (Fig. 3). Since the ARCTAS aircraft campaign covered mainly the North American Arctic, the observations made in the area north of $66^{\circ} \mathrm{N}$ were used. The dates of flights used for the comparison were 8, 9, 12, 16, and 17 April. The model results by the standard and the new schemes were analyzed at the grid closest to the locations and times of the observations. The observed and simulated $\mathrm{BC}$ concentrations were averaged for $1 \mathrm{~km}$ altitude intervals from the surface to $10 \mathrm{~km}$ of altitude. The observed vertical profile showed a maximum in the middle troposphere at $5 \mathrm{~km}$ of altitude. Although the standard scheme reproduced the increase from near the surface to the middle troposphere and the decrease from $5 \mathrm{~km}$ to the upper troposphere, the observed concentrations were underestimated by $24-42 \%$ in the middle troposphere. The negative biases were improved by the new scheme by increasing BC concentrations to 18$23 \mathrm{ng} \mathrm{m}^{-3}$ in the middle troposphere. These increases by the new scheme were caused by the longer lifetime of BC in the high latitudes as discussed above. Although the new scheme slightly underestimated the observed BC concentrations from 3 to $7 \mathrm{~km}$ of altitude, the model successfully captured the observed mean vertical profile, including the peak in the middle troposphere and the concentration level near the surface. The simulated vertical gradient from the surface to the middle troposphere was slightly weaker than that of the observations. One possible reason is that the upward transport of $\mathrm{BC}$ was underestimated by the model.

In addition to the Arctic region, we compared the model results with measurements in the major anthropogenic source regions: East Asia, Europe, and North America. For East Asia, we used BC data at nine rural and remote sites in China during 2006 and 2007 from Zhang et al. (2012). In addition, we used measurements at Fukue Island, a remote site located in western Japan (Kanaya et al., 2016). For North America, the data from the IMPROVE network for 20072011 were used (http://views.cira.colostate.edu/fed). In this study, we selected 43 IMPROVE sites located above $1500 \mathrm{~m}$ of altitude for comparison. For Europe, we used measure-

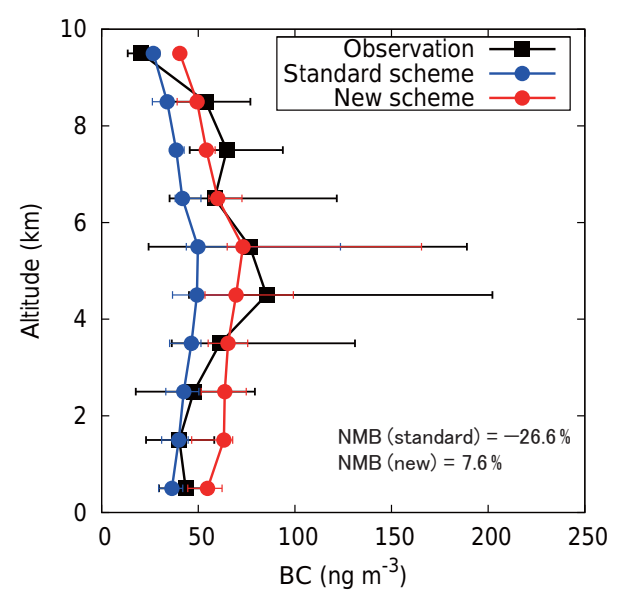

Figure 3. Mean vertical distributions of observed and simulated (blue solid line for standard scheme and red solid line for new scheme) BC over the region of the ARCTAS aircraft campaign in April 2008. Black squares and colored circles represent the median values. The error bars indicate the 25 th and 75 th percentiles.

ments at 12 sites by EUSAAR (European Supersites for Atmospheric Aerosol Research) for 2007-2011. The measurement data at EUSAAR sites were obtained from the EMEP and WDCA database (http://ebas.nilu.no). Figure 4 shows the scatterplot of the annual mean BC concentrations simulated by the model with the standard and new schemes in comparison to the observations in these three regions. The normalized mean bias (NMB) for East Asia was $-42 \%$, mainly because the model largely underestimated the observations at two sites located in western China. Without these two sites, the NMB for East Asia was improved to $-19 \%$. For North America, the simulated concentration levels were in good agreement with the observations $(\mathrm{NMB}=-6 \%)$. For Europe, the model tended to underestimate the observations $(\mathrm{NMB}=-33 \%)$. The possible reasons for the underestimations over East Asia and Europe are that BC emissions from these regions are underestimated and removals are overestimated by the model around the source regions. The differences between the standard and new schemes were small in all three regions (Fig. 4). This is because the BC aging time by the new scheme is similar to that of the standard scheme ( $\sim 1$ day) around the source regions in the midlatitudes, and wet scavenging by ice clouds is not so important in these regions. Because the BC concentrations tended to slightly increase in the new simulation, NMBs were improved by the new scheme from $-14--43 \%$ to $-6--42 \%$ (Fig. 4). Overall, these model-to-observations comparisons showed that our model simulations with the new scheme reasonably reproduced the observed BC levels, horizontal and vertical distributions, and spatial and temporal variabilities, thus demonstrating the model capability to examine the longrange transport of $\mathrm{BC}$ to the Arctic and its underlying physical and chemical mechanisms. 

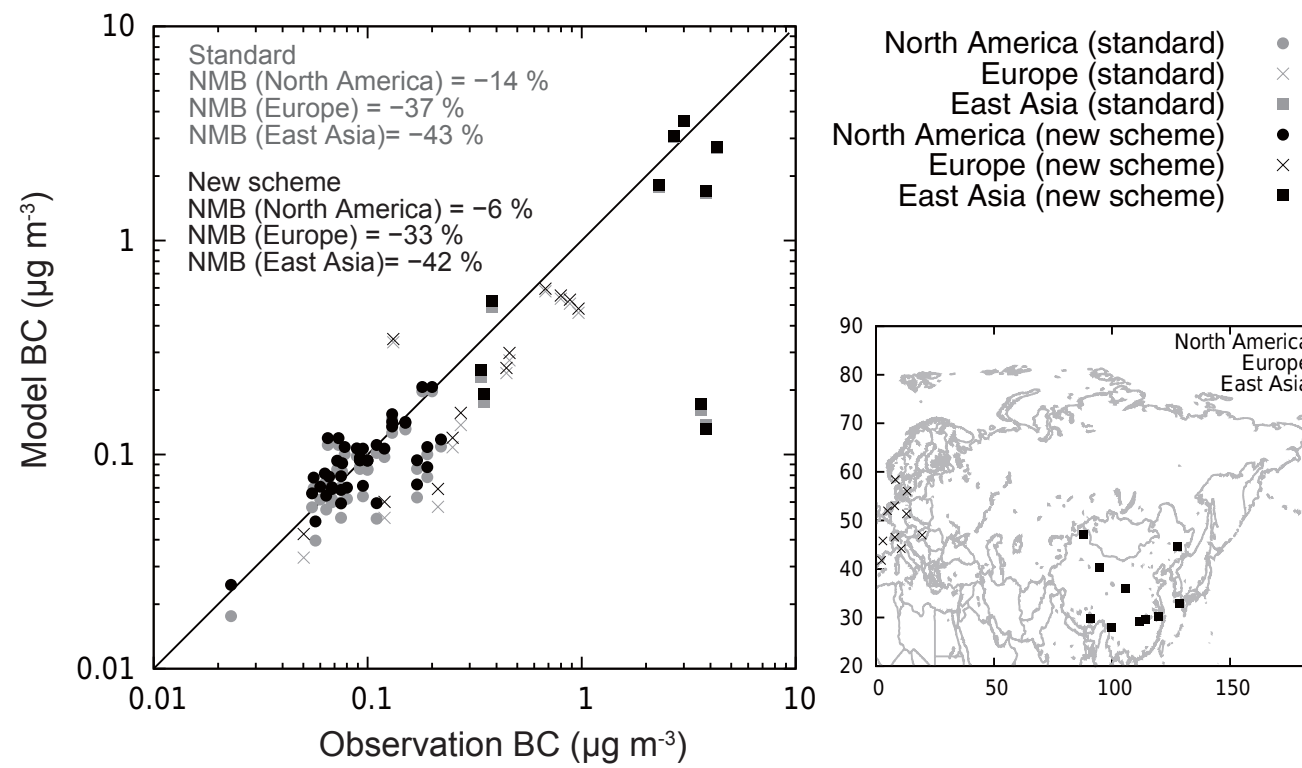

Figure 4. Scatterplots of annual mean BC concentrations modeled and observed at the surface sites in North America, Europe, and East Asia. Locations of the surface sites used for the comparisons (right).

\subsection{BC transport from anthropogenic sources to the Arctic}

Figure 5 shows the horizontal distributions of tagged $\mathrm{BC}$ tracers for major anthropogenic sources (ANs) and their fluxes at about $1 \mathrm{~km}$ of altitude in winter (DJF), spring (MAM), and summer (JJA). The horizontal fluxes were calculated by multiplying 6-hourly $\mathrm{BC}$ mass concentrations by horizontal wind speeds and were averaged for 3 months. East Asia (EAS-AN) was defined as the sum of Japan (JPNAN), the Korean Peninsula (KOR-AN), North China (NCHAN), and South China (SCH-AN). North America (NAMAN) was defined by adding Alaska and Canada (ALC-AN) to NAM-AN. BC originating from Russia (RUS-AN) is widely distributed over the Arctic during winter and has a large contribution (30-100 $\mathrm{ng} \mathrm{m}^{-3}$ ) over almost the entire Arctic region. The RUS-AN contribution showed a maximum in central Siberia, which is a large source region of gas flaring (Fig. 1; Huang et al., 2015). Northeastward winds prevailing over western Russia and central Siberia $\left(30-90^{\circ} \mathrm{E}\right)$ in winter probably played an important role in the transport of Russian BC to the Arctic (Fig. 7). Low precipitation in the cold season over Russia also contributed to the effective transport to the Arctic due to inefficient wet scavenging. Figure 7 shows that the precipitation level was less than $1 \mathrm{mmday}^{-1}$ over a large part of Russia during winter. Horizontal distributions of the wet scavenging ratio are also shown in Fig. 5. The wet scavenging ratio of RUS-AN was lower than the other source regions, especially during winter. The meteorological conditions in Russia during the cold season are characterized by low precipitation and cold temperatures at the surface. These meteorological conditions lead to ineffective removal and hence effective transport from Russia to the Arctic in winter and spring. In summer, the transport from RUS-AN to the Arctic was much weaker than in the other seasons (Fig. 5). This is because precipitation increased $\left(1-4 \mathrm{~mm} \mathrm{day}^{-1}\right)$ over Russia, leading to effective removal, and the circulation pattern also changed to the southeastward winds at $30-90^{\circ} \mathrm{E}$ during summer (Fig. 7). The seasonal variation in the largescale circulation pattern is caused by the intensified Siberian high during winter and its replacement by low pressure in summer (Stohl, 2006). Strong northeastward fluxes from Europe (EUR-AN) were seen at $1 \mathrm{~km}$ of altitude in winter and spring. BC originating from EUR-AN was enhanced over the European Arctic during winter $\left(20-50 \mathrm{ng} \mathrm{m}^{-3}\right)$ and spring. The transport from Europe to the Arctic was also attributed to northeastward winds blowing over northern Europe in the cold season (Fig. 7). This result is consistent with previous studies, which showed that high-latitude Eurasia (i.e., Russia and Europe) was an important source region of BC at the surface in the Arctic (Stohl, 2006; Hirdman et al., 2010).

The horizontal fluxes of East Asian BC (EAS-AN) and North American BC (NAM-AN) showed that long-range transport from East Asia and North America to the Arctic was inefficient in the lower troposphere. In winter, BC from East Asia was transported mainly southeastward by northwesterly winds associated with the winter monsoon circulation, which were dominant over northern China, Japan, and the northwestern Pacific (Fig. 7). BC from EAS-AN had a contribution of $10-20 \mathrm{ng} \mathrm{m}^{-3}$ in the Eurasian and North American Arctic during winter and spring. The NAM-AN contribution was estimated to be $5-10 \mathrm{ng} \mathrm{m}^{-3}$ in the North American Arctic during winter and spring. The transport from EAS-AN and NAM-AN was also weak during sum- 

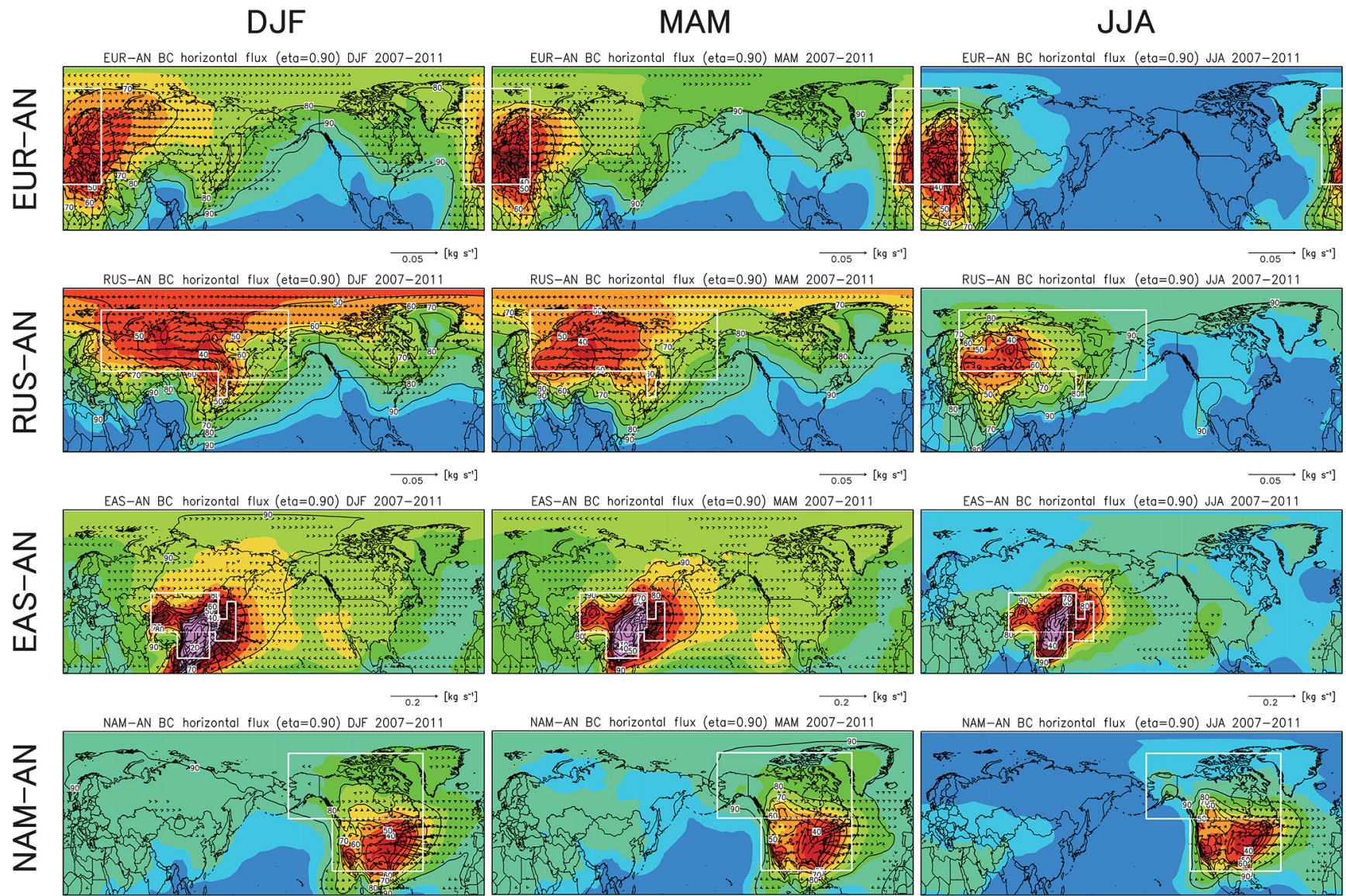

NAM-AN BC horizontal flux (eta $=0.90)$ MAM $2007-2011$
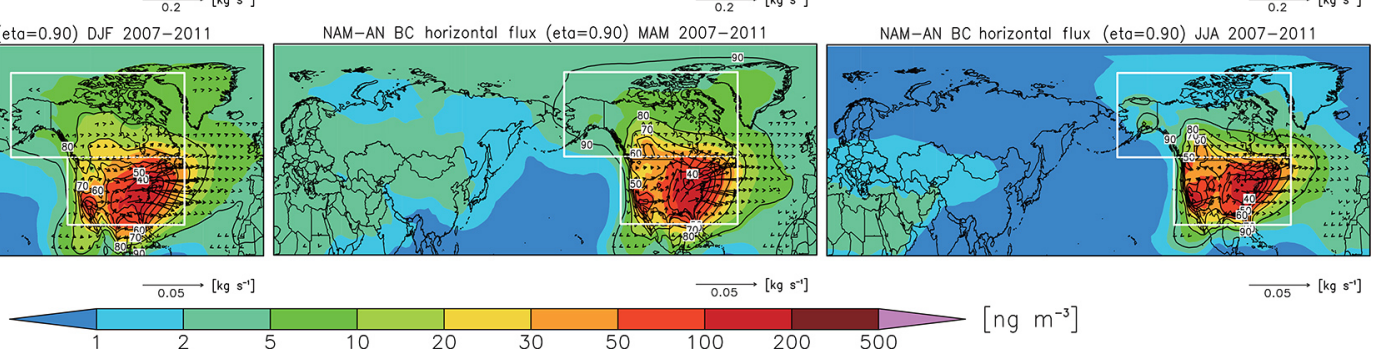

$\underset{0.05}{\longrightarrow}\left[\mathrm{kg} \mathrm{s}^{-1}\right]$

Figure 5. Distributions of seasonal mean concentrations (color) and horizontal fluxes (arrows) at $1 \mathrm{~km}$ of altitude for selected tagged BC tracers in winter (DJF), spring (MAM), and summer (JJA): EUR-AN, RUS-AN, EAS-AN, and NAM-AN. Wet scavenging ratios are also shown by solid lines. White lines indicate the source regions of BC tracers.

mer compared with the other seasons because precipitation increases around the source regions (Fig. 7).

The horizontal distributions of tagged BC tracers and their fluxes at $5 \mathrm{~km}$ of altitude are shown in Fig. 6, highlighting the long-range transport of $\mathrm{BC}$ in the middle troposphere from individual source regions. In the middle troposphere, $\mathrm{BC}$ originating from East Asia (EAS-AN) was transported eastward and northeastward in winter and spring. The eastward pathway from East Asia reached North America across the North Pacific. BC from East Asia also spread northeastward over the Sea of Okhotsk and eastern Siberia and reached the Arctic. It was further transported eastward over the Arctic Ocean. BC from East Asia had a contribution of $20-40 \mathrm{ng} \mathrm{m}^{-3}$ in the Eurasian Arctic in winter and spring. In winter, northward winds blowing over the Sea of Okhotsk, eastern Siberia, and the Bering Sea could play an important role in the poleward transport of EAS-AN BC (Fig. 7). Although seasonal mean northward winds in spring over these regions were weaker than those in winter (Fig. 7), the con- tribution of East Asian BC in spring was larger than that in winter (Fig. 5). This enhancement of EAS-AN BC during spring was not sufficiently explained by only the seasonal mean winds, suggesting that synoptic-scale disturbances on shorter timescales had an important role in the poleward transport from East Asia to the Arctic (Di Pierro et al., 2011). The patterns of the horizontal fluxes suggested that EASAN BC was transported mainly over the Sea of Okhotsk and eastern Siberia to the Arctic Ocean in winter and spring. This transport pathway agreed with the results of Di Pierro et al. (2011) that analyzed aerosol export events from East Asia to the Arctic region using satellite observations. The vertical profiles of aerosol observed by the CALIOP lidar onboard the CALIPSO satellite showed that the pollution plumes were transported from East Asia to the Arctic through eastern Siberia in the middle troposphere (Di Pierro et al., 2011). The distribution of the wet scavenging ratio showed that about $90 \%$ of BC from East Asia was deposited before arriving at the Arctic at $5 \mathrm{~km}$ of altitude during winter and 

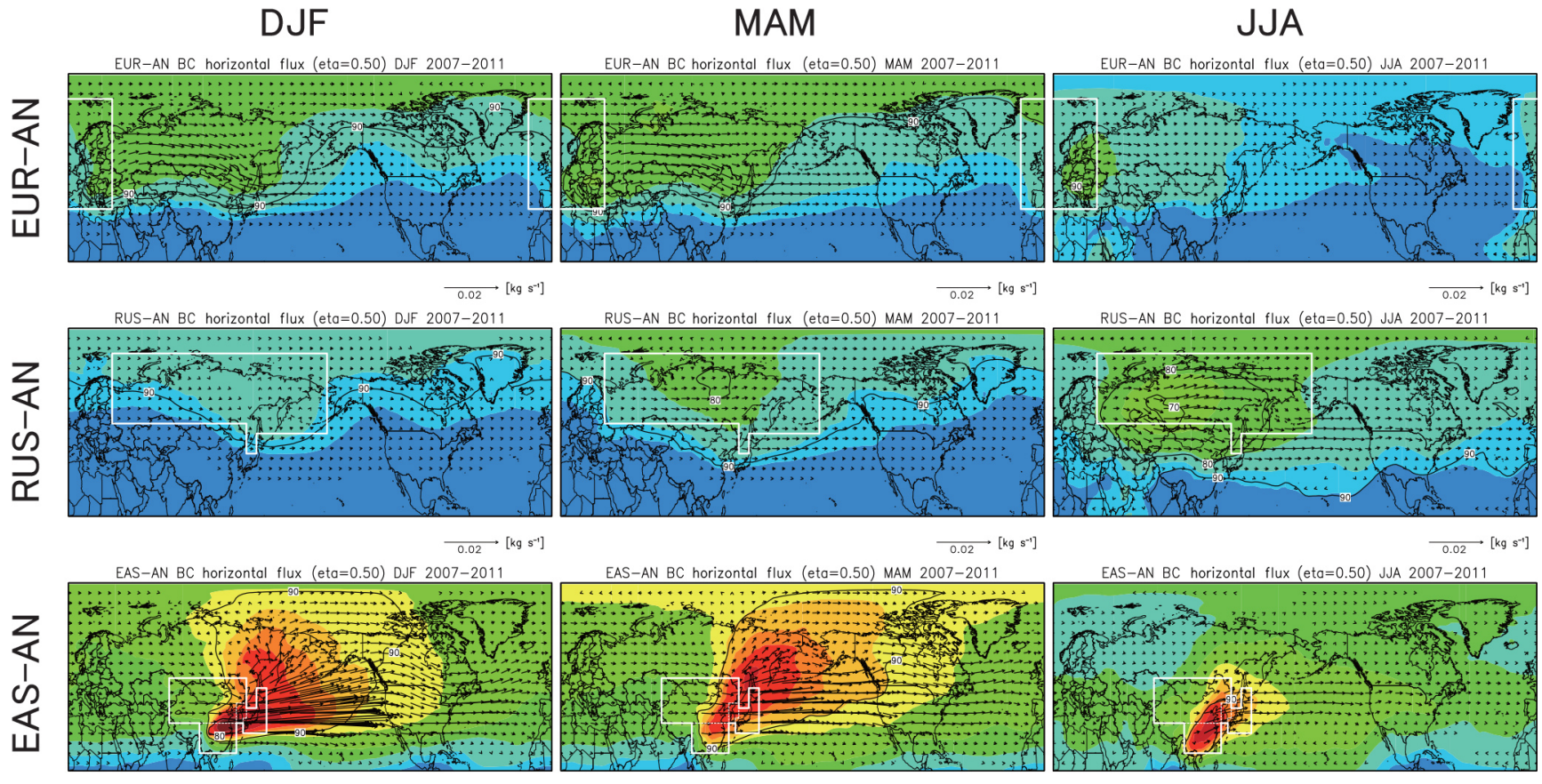

EAS-AN BC horizontal flux (eta $=0.50$ ) MAM 2007-201
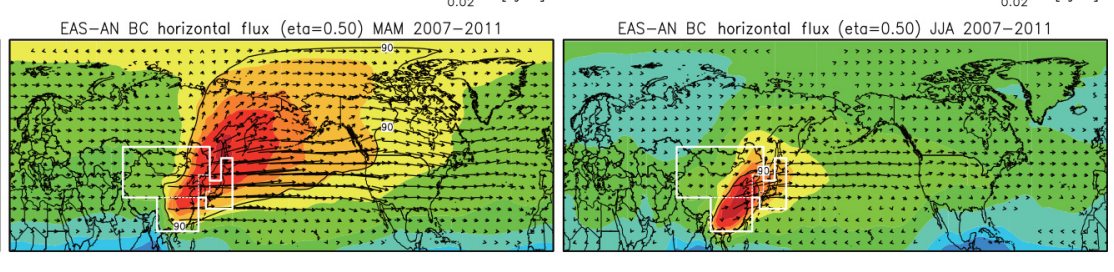

$\underset{0.075}{\left[\mathrm{~kg} \mathrm{~s}^{-1}\right]}$

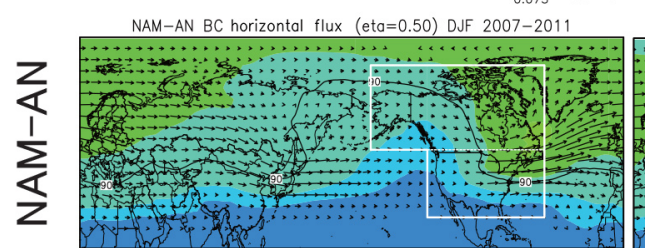

${ }_{0.075}^{\left[\mathrm{kg} \mathrm{s}^{-1}\right]}$

NAM-AN BC horizontal flux (eta $=0.50)$ MAM 2007-2011

$\underset{0.075}{[}[\mathrm{kg} \mathrm{s}-1]$

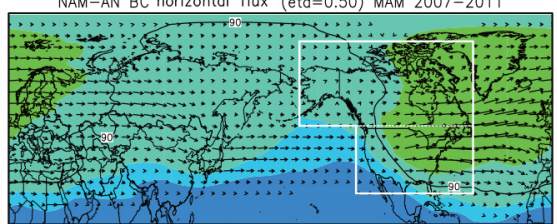

NAM-AN BC horizontal flux (eta $=0.50$ ) JJA 2007-2011

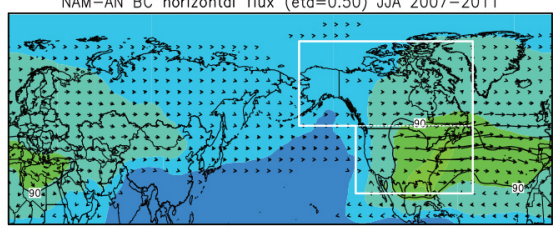

$\underset{0.02}{\longrightarrow}\left[\mathrm{kg} \mathrm{s}^{-1}\right]$

$\underset{0.02}{\longrightarrow}\left[\mathrm{kg} \mathrm{s}^{-1}\right]$

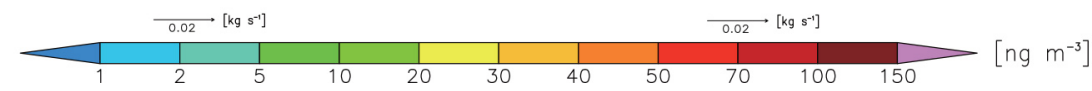

$\underset{0.02}{\longrightarrow}\left[\mathrm{kg} \mathrm{s}^{-1}\right]$

Figure 6. Same as Fig. 5 but for $5 \mathrm{~km}$ of altitude.

spring. The $\mathrm{BC}$ transport from East Asia was much weaker in summer than in winter and spring. BC from North America (NAM-AN) was also transported eastward and northeastward at $5 \mathrm{~km}$ of altitude during winter and spring. In addition to eastward transport to Europe across the North Atlantic, NAM-AN BC was transported from the eastern US to Greenland. The contribution of BC from Russia (RUS-AN) in the middle troposphere was much weaker compared with the lower troposphere, especially during winter (Fig. 5). The stable conditions of cold temperatures near the surface suppresses the upward transport of BC over Russia, especially in winter. BC from Europe (EUR-AN) at $5 \mathrm{~km}$ of altitude was also smaller than at $1 \mathrm{~km}$ of altitude.

Figure 8 shows the longitude-height distributions of the meridional fluxes of $\mathrm{BC}$ from individual source regions at $66^{\circ} \mathrm{N}$ in winter, spring, and summer. From these figures, we can identify important regions where inflows of $\mathrm{BC}$ from major source regions to the Arctic occur. Significant BC transport from EUR-AN toward the Arctic was seen at $0-60^{\circ} \mathrm{E}$ below $2 \mathrm{~km}$ of altitude in winter and spring. Transport from RUS-AN to the Arctic occurred mainly in the lower tropo- sphere at $30-90^{\circ} \mathrm{E}$. During winter, low temperatures at the surface lead to a thermally stable stratification that reduces vertical mixing (Barrie, 1986). Due to the stable conditions over Russia, the inflow from RUS-AN to the Arctic was concentrated below $1 \mathrm{~km}$ of altitude during winter. A strong inflow from EAS-AN to the Arctic was seen in the middle to upper troposphere, and the low-level transport to the Arctic was weak in contrast to EUR-AN and RUS-AN. BC from EAS-AN was uplifted during long-range transport to the Arctic due to the large latitudinal gradient in the potential temperature (Klonecki et al., 2003). A strong poleward transport of EAS-AN BC occurred at $130-180^{\circ} \mathrm{E}$ at 3-8 km of altitude during winter. Although the inflow from EAS-AN became slightly weaker than that in winter, a similar structure to winter was also seen during spring. This result was in good agreement with the observational study by Di Pierro et al. (2011), which showed that the meridional transport of aerosol originating from East Asia to the Arctic took place at $3-7 \mathrm{~km}$ of altitude. The Arctic lower troposphere is isolated by the closed polar dome, which is formed by isentropic surfaces of lower potential temperatures, and pollutants can- 

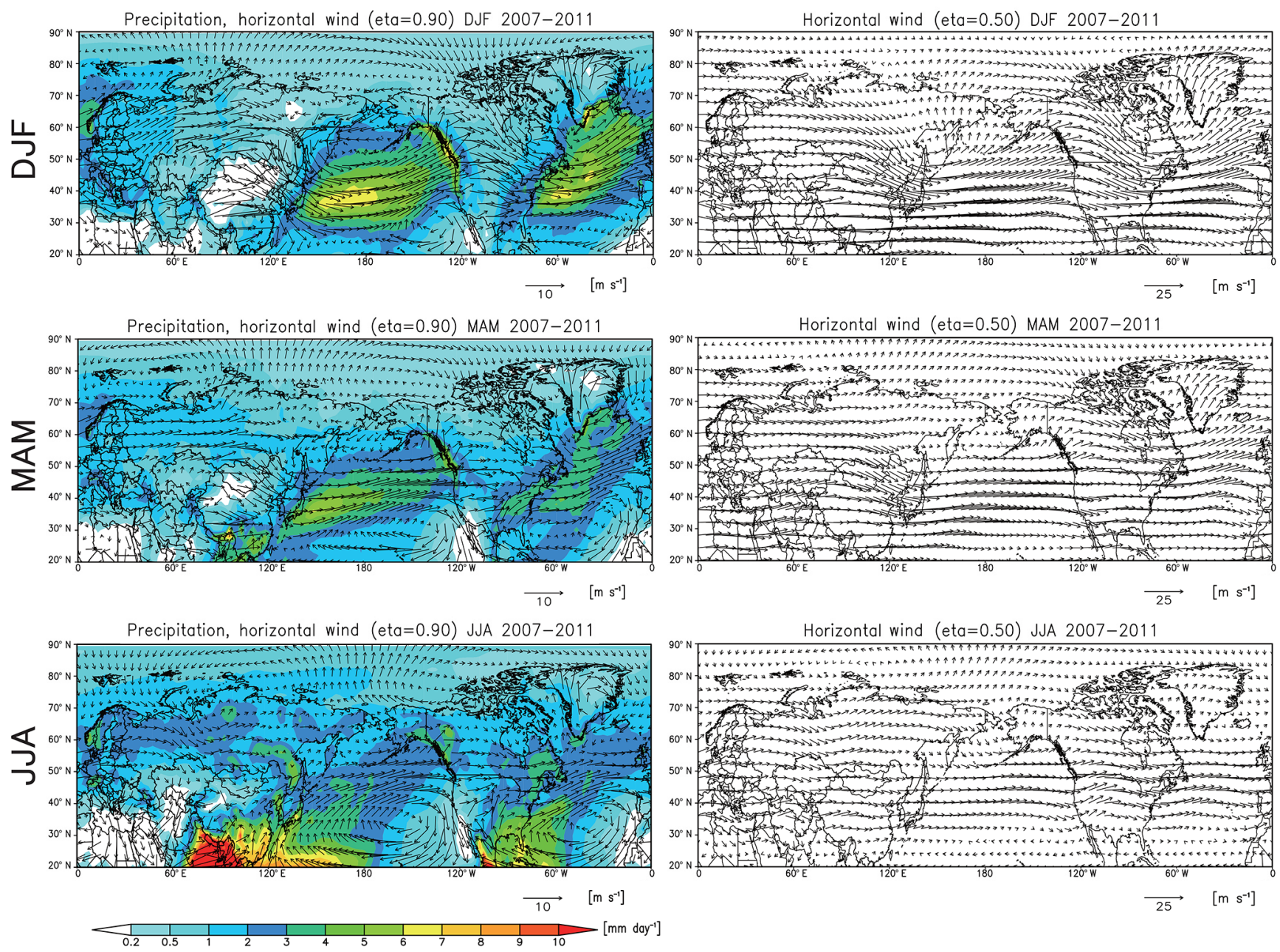

Figure 7. Distributions of seasonal mean precipitation (color) and horizontal winds (arrows) of GEOS-5 at $1 \mathrm{~km}$ (a) and $5 \mathrm{~km}$ (b) altitudes in winter (DJF), spring (MAM), and summer (JJA).

not easily penetrate into the Arctic from outside of the polar front (Barrie, 1986). East Asia is located south of the polar dome, and EAS-AN BC is emitted at higher potential temperatures. As a result, the low-level transport of East Asian $\mathrm{BC}$ into the Arctic was weak and it was transported at higher altitudes (Klonecki et al., 2003; Stohl, 2006). In summer, BC transport from EAS-AN to the Arctic was much weaker in the middle troposphere and was confined in the upper troposphere. BC transport from NAM-AN to the Arctic across $66^{\circ} \mathrm{N}$ was also seen in the middle to upper atmosphere, and the inflow in the lower troposphere was weak, similarly to EAS-AN. This is because North American BC is also emitted at higher potential temperatures and was transported to the Arctic above the polar dome. The inflow from NAM-AN to the Arctic occurred mainly at $30-90^{\circ} \mathrm{W}$ at $3-8 \mathrm{~km}$ of altitude. Pollutants exported from East Asia and North America experience ascent transport by vertical mixing, such as warm conveyer belts from the boundary layer to the free tro- posphere, and are eventually transported to the Arctic in the middle to upper troposphere (Klonecki et al., 2003).

The distribution of the wet scavenging ratio at $66^{\circ} \mathrm{N}$ showed that about $90 \%$ of the EAS-AN BC was removed from the atmosphere during long-range transport to the Arctic in winter and spring (Fig. 8). This value is consistent with the transport efficiency (i.e., the fraction of BC not removed during transport) from Asia (13\%) derived from the $\mathrm{BC} / \triangle \mathrm{CO}$ ratio over the Northern American Arctic observed during the ARCTAS spring campaign (Matsui et al., 2011). The wet scavenging ratio of NAM-AN (85-90\%) was similar to that of EAS-AN. The wet scavenging ratio in the strong inflow regions of RUS-AN across $66^{\circ} \mathrm{N}\left(30-90^{\circ} \mathrm{E}\right.$, below $1 \mathrm{~km}$ of altitude) was $30-50 \%$ during these seasons. Thus, the wet removal of the RUS-AN BC was much less than that of EAS-AN and NAM-AN, leading to efficient transport to the Arctic. The dry conditions with low precipitation in highlatitude Eurasia reduce wet deposition and lead to a longer lifetime of $\mathrm{BC}$ in the Arctic troposphere, especially in win- 

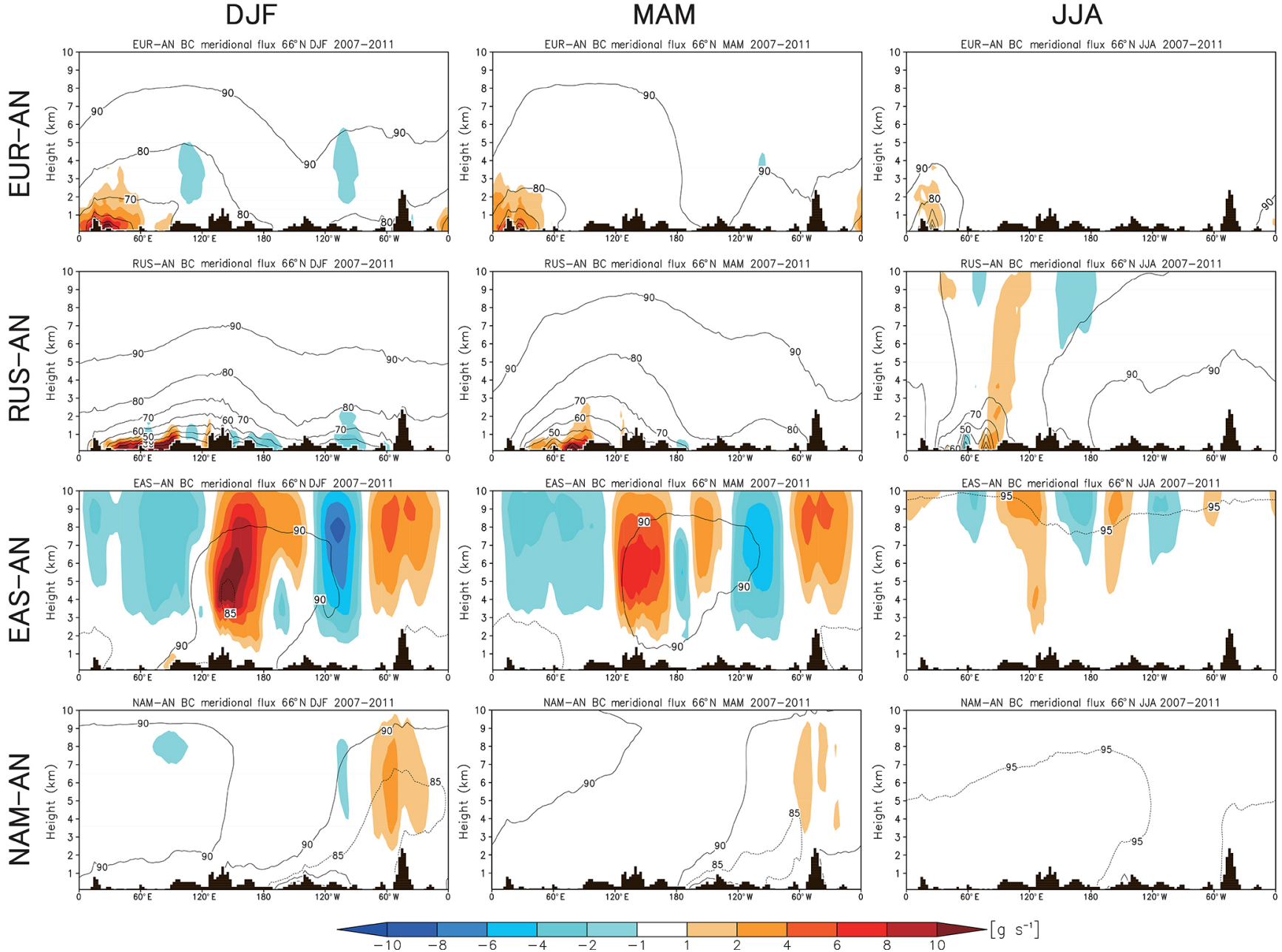

Figure 8. Longitude-height cross sections of mean net meridional fluxes at $66^{\circ} \mathrm{N}$ for selected tagged $\mathrm{BC}$ tracers in winter, spring, and summer: EUR-AN, RUS-AN, EAS-AN, and NAM-AN. Wet scavenging ratios are also shown by solid lines.

ter. The wet scavenging ratio of EUR-AN BC at $66^{\circ} \mathrm{N}$ was estimated to be $40-80 \%$ at $0-60^{\circ} \mathrm{E}$ below $2 \mathrm{~km}$ of altitude during winter and spring.

\subsection{Relative contributions from anthropogenic and biomass burning emissions}

Figure 9 shows the seasonal variations in the individual source contributions averaged for the Arctic $\left(66-90^{\circ} \mathrm{N}\right)$ from the surface to $10 \mathrm{~km}$ of altitude. The total contribution from anthropogenic sources other than the four major source regions (Europe: EUR-AN, Russia: RUS-AN, East Asia: EASAN, and North America: NAM-AN) was aggregated to OTHAN. For biomass burning (BB), the contributions from Russia (seven regions) and from Alaska and Canada (three regions) were aggregated to SIB-BB and ALC-BB, respectively. The total contribution from biomass burning sources other than SIB-BB and ALC-BB was defined as OTH-BB. In
Fig. 9, the relative contributions from individual sources to the total BC concentrations are also shown.

Due to the effective transport in the lower troposphere (Fig. 5), the contribution from RUS-AN increased from late autumn to early spring mainly below $2 \mathrm{~km}$ of altitude. It was largest near the surface and decreased with altitude in these seasons (Fig. 9). This structure reflected a thermally stable stratification by cold temperatures at the surface during the cold season (Klonecki et al., 2003; Stohl, 2006). RUS-AN $\mathrm{BC}$ had a relative contribution of $40-70 \%$ to Arctic BC below $1 \mathrm{~km}$ of altitude except during summer. The contribution from EUR-AN also increased below $2 \mathrm{~km}$ of altitude in winter and early spring, accounting for $10-20 \%$ of the Arctic BC. EAS-AN BC increased with altitude from the surface and had the largest contribution at about $5 \mathrm{~km}$ of altitude due to strong poleward transport in the middle troposphere (Figs. 6 and 8). The seasonal variation in the contribution from EAS-AN showed a maximum in early spring (March) and a minimum during summer. The relative con- 


\section{Arctic $\mathrm{BC}\left(66-90^{\circ} \mathrm{N}\right)$}
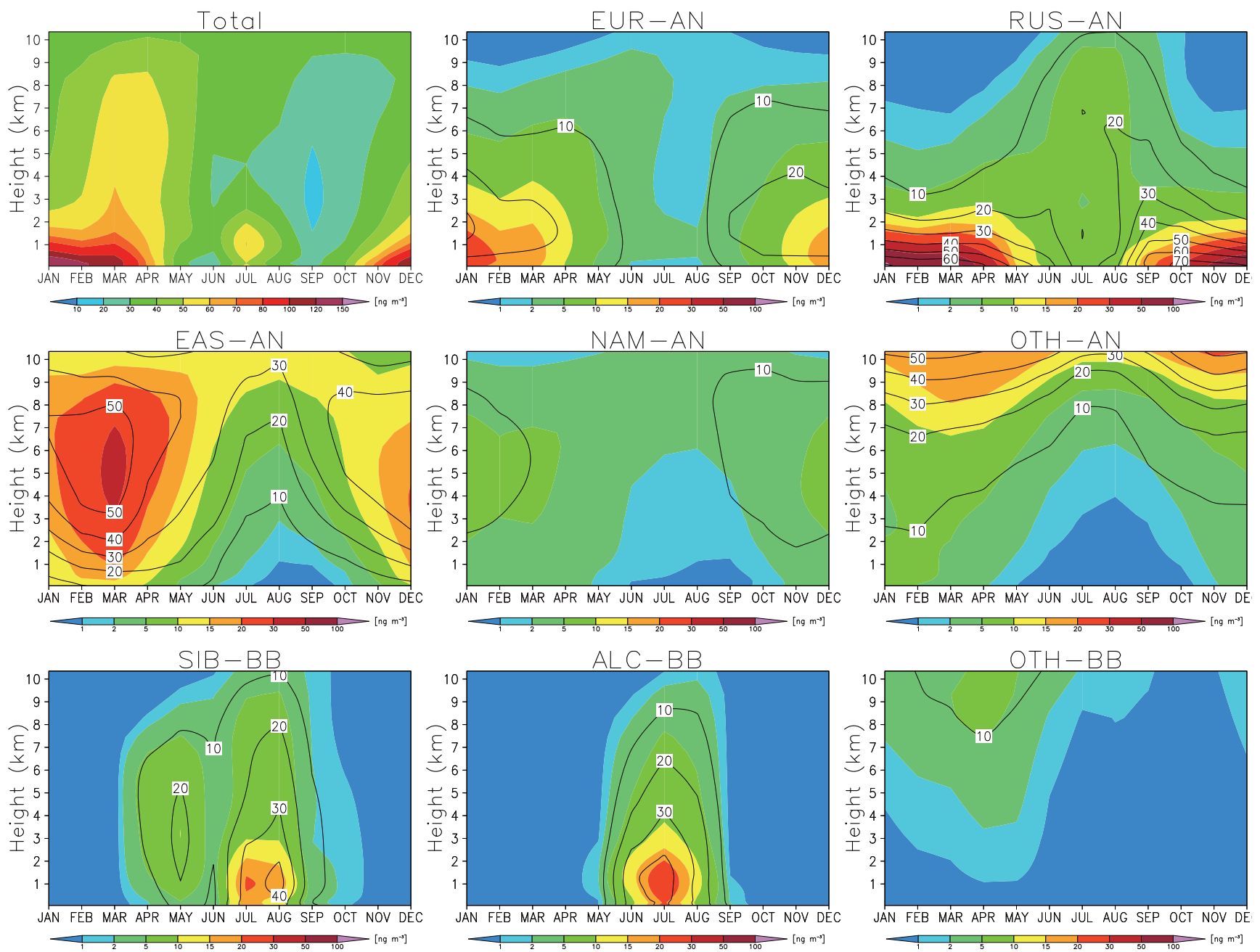

Figure 9. Month-altitude cross sections of mean BC concentrations from individual sources in the Arctic $\left(66-90^{\circ} \mathrm{N}\right)$. Relative contributions to total $\mathrm{BC}$ concentrations are also shown by solid lines.

tribution from EAS-AN was estimated to be $30-50 \%$ in the middle and upper troposphere in winter and spring. The contribution from NAM-AN showed a maximum in winter at about $5 \mathrm{~km}$ of altitude. Because BC from East Asia and North America located at relatively lower latitudes was emitted at higher potential temperatures, it was uplifted in the middle troposphere during long-range transport to the Arctic (Klonecki et al., 2003). OTH-AN, which consisted mainly of the anthropogenic sources in the northern low latitudes and the Southern Hemisphere, had a contribution in the upper troposphere above about $8 \mathrm{~km}$ of altitude. In contrast to the anthropogenic sources, the contributions of biomass burning emissions from SIB-BB and ALC-BB increased in summer because boreal fires in Siberia, Alaska, and Canada increased from late spring to autumn. The relative contributions of SIB-
BB and ALC-BB were estimated to be $20-40$ and $30-40 \%$, respectively, during summer in the lower troposphere.

Figure 10 shows the seasonal variations in the contributions from individual sources to $\mathrm{BC}$ mass concentrations near the surface and at about $5 \mathrm{~km}$ of altitude averaged for the Arctic region $\left(66-90^{\circ} \mathrm{N}\right)$. The wet scavenging ratios of the anthropogenic sources (EUR-AN, RUS-AN, EAS-AN, and NAM-AN) are also shown to highlight the role of wet removal processes in the seasonal variations in Arctic BC. Near the surface, RUS-AN was a dominant contributor of 40$70 \%$ on a monthly basis, followed by EUR-AN (10-20\%) and EAS-AN (5-15\%) in winter, spring, and autumn. Thus, the contributions of anthropogenic sources were remarkably larger than those of biomass burning sources during the seasons except summer. SIB-BB and ALC-BB had a substantial contribution of $10-40$ and $30-40 \%$, respectively, dur- 

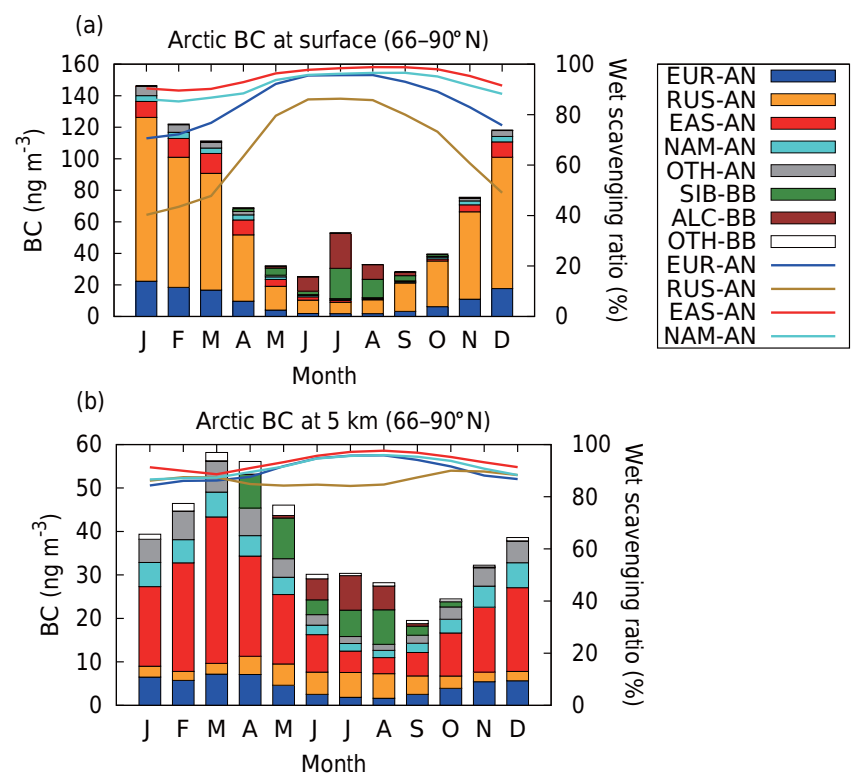

Figure 10. Seasonal variations in mean BC concentrations (left axis) from individual sources (a) near the surface and (b) at $5 \mathrm{~km}$ of altitude in the Arctic $\left(66-90^{\circ} \mathrm{N}\right)$. Mean wet scavenging ratios (right axis) for major anthropogenic source regions are also shown by solid lines: EUR-AN, RUS-AN, EAS-AN, and NAM-AN.

ing summer, resulting in a larger contribution from biomass burning than from anthropogenic sources in this season. At $5 \mathrm{~km}$ of altitude, EAS-AN was the most important, accounting for 30-60\% on a monthly basis, followed by small but substantial contributions from EUR-AN (10-20\%), NAMAN (10-15\%), RUS-AN (5-20\%), and OTH-AN (10-15\%) in winter, spring, and autumn. The contributions of SIB-BB and ALC-BB were substantial in spring (15-20\% from SIBBB) and summer (10-30\% from SIB-BB and 15-30\% from ALC-BB). The biomass burning contribution was comparable to that of the anthropogenic sources in summer.

Near the surface, the contribution from RUS-AN showed a large seasonal variation with a maximum during winter $\left(\sim 100 \mathrm{ng} \mathrm{m}^{-3}\right)$ and a minimum in summer $\left(\sim 10 \mathrm{ng} \mathrm{m}^{-3}\right.$; Fig. 10). BC originating from Russia was the most important to the Arctic BC near the surface, except during summer, and hence had a large influence on the seasonal variation in the total BC concentration over the Arctic. The wet scavenging ratio of RUS-AN had a large seasonal variation from $20 \%$ in winter to $70 \%$ during summer. Although the wet scavenging ratios of all four anthropogenic sources (EUR-AN, RUS-AN, EAS-AN, and NAM-AN) decreased during winter and increase in summer, the amplitude of RUS-AN was the greatest among these sources. In addition, the wet scavenging ratio of RUS-AN was the lowest among the major anthropogenic sources in all seasons, leading to a significant contribution to Arctic BC. The seasonal variation in the contribution from EUR-AN near the surface was similar to that of RUS-AN (Figs. 9 and 10). EUR-AN was the most impor- tant during winter with a contribution of $\sim 20 \mathrm{ng} \mathrm{m}^{-3}$ to the Arctic. The wet scavenging ratio of EAS-AN was the highest among the four major anthropogenic sources and exceeded $90 \%$ in all seasons near the surface.

In the middle troposphere (at $\sim 5 \mathrm{~km}$ of altitude), the seasonal variation in EAS-AN BC showed an increase in spring and a decrease during summer (Figs. 9 and 10). Due to the large contribution of EAS-AN, the total BC concentration also showed a maximum in spring, which was different from the seasonal variation near the surface (winter maximum). Although the wet scavenging ratio of EAS-AN was the largest among the major anthropogenic sources, the contribution from EAS-AN was dominant except during summer in the middle troposphere. This is because the BC emission of EAS-AN is much larger than that from the other sources as discussed below. Because EAS-AN BC was uplifted from the lower troposphere to the middle and upper troposphere during long-range transport, its contribution was larger in the middle troposphere than near the surface. Although the wet scavenging ratio of NAM-AN was slightly less than that of EAS-AN, the contribution from NAM-AN was about $10 \mathrm{ng} \mathrm{m}^{-3}$ in winter and spring and was smaller than that from EAS-AN. The contribution from RUS-AN at about $5 \mathrm{~km}$ of altitude was much less compared with that near the surface, especially in winter and spring (Figs. 9 and 10). Because of the thermally stable conditions over Russia in the cold season, the upward transport of RUS-AN BC to the middle and upper troposphere is suppressed. The contribution of EUR-AN in the middle troposphere was also smaller than that near the surface.

\subsection{Source contributions to the annual budget of $\mathrm{BC}$ in the Arctic}

In Table 1, we summarize the budgets of each BC tracer averaged for 2007-2011 (see Table S1 for more detailed source regions). The annual total amount of the poleward BC flux from East Asia (EAS-AN) across $66^{\circ} \mathrm{N}$, which was calculated by 6 -hourly concentrations and northward winds $(v>0)$, was estimated to be $175.4 \mathrm{Gg} \mathrm{yr}^{-1}$, corresponding to about $10 \%$ of the total emissions $\left(1844.9 \mathrm{Gg} \mathrm{yr}^{-1}\right)$. The deposition amount of EAS-AN BC on the Arctic region (66$90^{\circ} \mathrm{N}$ ) was $12.3 \mathrm{Gg} \mathrm{yr}^{-1}$, which was about $1 \%$ of the EASAN emissions. Thus, a large part of the EAS-AN BC transported to the Arctic was transported outside of the Arctic without depositing onto the surface within the Arctic. Although the fraction of $\mathrm{BC}$ from East Asia transported to the Arctic was lower than the other anthropogenic sources (EUR-AN, RUS-AN, and NAM-AN) due to effective wet removal (Fig. 10), the inflow flux of EAS-AN was the largest among the four major sources. This is because the emissions of EAS-AN are much larger than those from the other source regions (Table 1). On the other hand, the emissions from Russia (RUS-AN; $196.8 \mathrm{Gg} \mathrm{yr}^{-1}$ ) were relatively small among the major anthropogenic sources, but the inflow flux was the 
Table 1. Budgets of BC from individual sources for the period 2007-2011.

\begin{tabular}{|c|c|c|c|c|c|c|c|}
\hline \multirow[t]{2}{*}{ Tracer $^{\mathrm{a}}$} & \multirow[t]{2}{*}{$\begin{array}{l}\text { Emission }^{\mathrm{c}}, \\
\mathrm{Gg} \mathrm{yr}^{-1}\end{array}$} & \multirow[t]{2}{*}{$\begin{array}{l}\text { Poleward flux across } \\
66^{\circ} \mathrm{N}(v>0), \mathrm{Gg} \mathrm{yr}^{-1}\end{array}$} & \multirow[t]{2}{*}{$\begin{array}{r}\text { Burden in the } \\
\text { Arctic, Gg }\end{array}$} & \multicolumn{2}{|c|}{$\begin{array}{l}\text { Deposition to the } \\
\text { Arctic, } \mathrm{Gg} \mathrm{yr}^{-1}\end{array}$} & \multicolumn{2}{|c|}{ Lifetime, days } \\
\hline & & & & Wet & Dry & Global & Arctic \\
\hline EUR-AN & $353.7(2.6)$ & 76.1 & 0.9 & 18.2 & 4.8 & 6.4 & 14.2 \\
\hline RUS-AN & $196.8(22.2)$ & 103.0 & 1.5 & 26.7 & 15.2 & 9.1 & 12.9 \\
\hline EAS-AN ${ }^{b}$ & $1844.9(0.0)$ & 175.4 & 1.9 & 10.4 & 1.9 & 6.4 & 57.5 \\
\hline NAM-AN ${ }^{b}$ & $342.2(0.6)$ & 45.5 & 0.5 & 4.5 & 0.8 & 5.7 & 34.1 \\
\hline OTH-AN ${ }^{b}$ & $2946.9(0.1)$ & 110.5 & 1.2 & 4.0 & 0.7 & 7.6 & 92.7 \\
\hline SIB-BB ${ }^{b}$ & $114.2(4.9)$ & 42.5 & 0.5 & 15.5 & 2.3 & 7.9 & 10.1 \\
\hline ALC-BB ${ }^{b}$ & $64.0(5.6)$ & 27.0 & 0.4 & 12.6 & 2.1 & 6.3 & 8.6 \\
\hline OTH-BB ${ }^{b}$ & $1718.3(0.0)$ & 21.9 & 0.2 & 1.3 & 0.1 & 8.0 & 57.9 \\
\hline Total & $7580.9(35.9)$ & 601.8 & 7.1 & 93.1 & 27.9 & 7.3 & 21.3 \\
\hline
\end{tabular}

a AN and BB indicate anthropogenic and biomass burning sources, respectively. ${ }^{\mathrm{b}}$ EAS-AN (East Asia) is the sum of JPN-AN, KOR-AN, NCH-AN, and SCH-AN; NAM-AN (North America) is the sum of NAM-AN, and ALC-AN; OTH-AN is the sum of anthropogenic sources other than EUR-AN, RUS-AN, EAS-AN and NAM-AN; SIB-BB is the sum of WRU-BB, S1-BB, S2-BB, S3-BB, S4-BB, S5-BB, and S6-BB; ALC-BB is the sum of ALC-BB, WCA-BB, and EAC-BB; and OTH-BB is the sum of biomass burning sources other than SIB-BB and ALC-BB. ${ }^{\mathrm{C}}$ Values in brackets denote emissions from north of $66^{\circ} \mathrm{N}$

second largest $\left(103.0 \mathrm{Gg} \mathrm{yr}^{-1}\right)$. This is due to the effective transport from Russia to the Arctic, especially during winter and spring (Figs. 5 and 10).

The global lifetimes of BC tracers, which were defined as the burden divided by the annual total deposition, were estimated to be 5.7-9.1 days (Table 1). The average lifetime of 7.3 days agreed with the value of the multi-model mean in the ACCMIP project (7.4 days; Lee et al., 2013) and with those reported by previous studies (e.g., 7.3 days from Koch and Hansen, 2005, and 5.9 days from Wang et al., 2011). The $\mathrm{BC}$ lifetimes of each tracer in the Arctic $\left(66-90^{\circ} \mathrm{N}\right)$ were estimated to be 8.6-92.7 days. The lifetime of EAS-AN BC in the Arctic (57.5 days) was longer than that of EUR-AN (14.2 days) and RUS-AN (12.9 days) because East Asia, BC was distributed mainly in the middle troposphere (Fig. 9) and its deposition to the Arctic was smaller than EUR-AN and RUS-AN (Table 1). The average lifetime of 21.3 days in the Arctic was close to the 20.0-day the multi-model mean in the AMAP (Arctic Monitoring and Assessment Programme) models (Mahmood et al., 2016).

Table 2 summarizes the relative contributions from individual sources to the annual mean BC concentrations, burden, and deposition over the Arctic $\left(66-90^{\circ} \mathrm{N}\right)$. In Table 2, the tagged $\mathrm{BC}$ tracers were aggregated to five anthropogenic and three biomass burning sources. As expected from Figs. 9 and 10, Russia (RUS-AN) was the most important contributor to the $\mathrm{BC}$ concentrations at the surface, accounting for $61.8 \%$. Europe (EUR-AN) had the second largest contribution at the surface $(13.4 \%)$ among the sources. The relative contribution from East Asia (EAS-AN) was estimated to be $8.0 \%$. This result is similar to previous studies, which showed that northern Eurasia (Europe and Russia) was the dominant source region and East Asia had a smaller contribution at the Arctic surface (Shindell et al., 2008; Hirdman
Table 2. Relative contributions from individual sources to the annual mean $\mathrm{BC}$ concentrations at the surface and $5 \mathrm{~km}$ of altitude, annual deposition, and burden in the Arctic $\left(66-90^{\circ} \mathrm{N}\right)(\%)$.

\begin{tabular}{lrrrr}
\hline Tracer $^{\mathrm{a}}$ & Surface & $5 \mathrm{~km}$ & Burden & Deposition \\
\hline EUR-AN & 13.4 & 12.2 & 12.6 & 19.0 \\
RUS-AN & 61.8 & 9.8 & 21.0 & 34.7 \\
EAS-AN $^{\mathrm{b}}$ & 8.0 & 40.6 & 27.4 & 10.1 \\
NAM-AN $^{\mathrm{b}}$ & 3.1 & 10.4 & 6.9 & 4.3 \\
OTH-AN $^{\mathrm{b}}$ & 2.9 & 10.9 & 17.0 & 3.9 \\
SIB-BB $^{\mathrm{b}}$ & 5.2 & 8.5 & 7.0 & 14.7 \\
ALC-BB $^{\mathrm{b}}$ & 5.2 & 4.3 & 4.9 & 12.1 \\
OTH-BB $^{\mathrm{b}}$ & 0.4 & 3.3 & 3.2 & 1.2 \\
\hline
\end{tabular}

a AN and BB indicate anthropogenic and biomass burning sources,

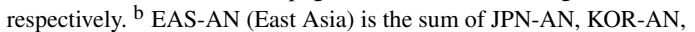
NCH-AN, and SCH-AN; NAM-AN (North America) is the sum of NAM-AN, and ALC-AN; OTH-AN is the sum of anthropogenic sources other than EUR-AN, RUS-AN, EAS-AN, and NAM-AN; SIB-BB is the sum of WRU-BB, S1-BB, S2-BB, S3-BB, S4-BB, S5-BB, and S6-BB; ALC-BB is the sum of ALC-BB, WCA-BB and EAC-BB; and OTH-BB is the sum of biomass burning sources other than SIB-BB and ALC-BB.

et al., 2010; Sharma et al., 2013; Wang et al., 2014). The larger contribution from Russia than Europe in this study is consistent with recent studies using newly developed emissions, including gas flaring (Stohl et al., 2013; Huang et al., 2015). The contributions from biomass burning in Siberia (SIB-BB) and Alaska and Canada (ALC-BB) were about $5 \%$ at the surface. Thus, the contribution of anthropogenic emissions was dominant at the surface over the Arctic, accounting for $90 \%$ of the annual mean.

In the middle troposphere ( $5 \mathrm{~km}$ of altitude), East Asia (EAS-AN) had the largest contribution of $40.6 \%$ to the annual mean $\mathrm{BC}$ concentration over the Arctic. Among the source regions in East Asia, North China (NCH-AN) had the 
most significant contribution of $29.4 \%$ (see the Supplement, Table S2). The dominance from East Asia in the middle troposphere is consistent with previous studies (Wang et al., $2011,2014)$. The relative contribution from RUS-AN was $9.8 \%$ at $5 \mathrm{~km}$ of altitude, which was much less than that at the surface $(62 \%)$. Thus, the main contributor to Arctic $\mathrm{BC}$ differed with altitude. This is because the transport pathways from individual sources to the Arctic are different as described before (Figs. 5-7). The transport from East Asia to the Arctic was characterized by uplifting to the middle and upper troposphere during long-range transport (Figs. 6 and 7). BC from Russia was transported to the Arctic mainly in the lower troposphere due to the stable conditions during the cold season (Figs. 5 and 7). In the context of air pollution over the Arctic, BC from Russia and Europe is more important due to the large contributions near the surface during the Arctic haze season. In addition, BC in the lower troposphere effectively warms the Arctic surface (Flanner, 2013). On the other hand, BC in the middle troposphere is more important to radiative forcing at the top of the atmosphere and causes atmospheric heating in the lower and middle troposphere (Flanner, 2013). Thus, it is important to understand altitudinally varying source contributions to Arctic BC because the Arctic climate response is sensitive to the vertical distribution of $\mathrm{BC}$ in the Arctic.

For the BC burden over the Arctic, the contribution from East Asia (EAS-AN) was the most important and accounted for $27.4 \%$ of the annual mean. The second largest contributor to the $\mathrm{BC}$ burden over the Arctic was Russia (21.0\%). This result is consistent with AMAP (2015), which showed that the main contributors to the BC burden in the Arctic were East and South Asia and Russia. Wang et al. (2014) also estimated that East Asia and Northern Asia (consisting mainly of Russia) had the two largest contributions of 23.4 and $22.6 \%$, respectively, to the BC burden in the Arctic, which is consistent with this study. Bourgeois and Bey (2011) showed that Siberia, Asia, and Europe had comparable contributions to the Arctic $\mathrm{BC}$ burden. In this study, other anthropogenic sources (OTH-AN) also had a significant contribution of $17.0 \%$. In OTH-AN, South Asia (SASAN) provided the most important contribution of $8.7 \%$ (see the Supplement, Table S2).

We also quantitatively estimated the relative contributions from each source to the total deposition of BC to the Arctic region (Table 2). The contribution from Russia (RUS-AN) was the largest (34.7\%). The second largest was the contribution from EUR-AN $(19.0 \%)$. Thus, the major sources of deposition on the Arctic were identical to the dominant contributors to the BC concentrations at the surface. This is similar to previous studies, which showed that Europe and Russia provided the two largest contributions to $\mathrm{BC}$ deposition to the Arctic, while East Asia contributed less to deposition than to burden (Huang et al., 2010; Bourgeois and Bey, 2011; Sharma et al., 2013; Wang et al., 2014), although some studies estimated a larger contribution from Europe than from
Russia (Huang et al., 2010; Sharma et al., 2013; Wang et al., 2014). The contributions of biomass burning in Siberia (SIBBB) and Alaska and Canada (ALC-BB) were also important, accounting for 14.7 and $12.1 \%$, respectively. These values of biomass burning sources were larger than their relative contributions to $\mathrm{BC}$ concentrations at the surface $(\sim 5 \%)$. This is because $\mathrm{BC}$ deposition is enhanced during summer due to increased precipitation, and the contributions from SIB-BB and ALC-BB to the BC concentrations become large in this season in contrast to the anthropogenic sources (Fig. 10).

We estimated interannual variations in relative contributions from individual sources to Arctic BC and found that the results of each year were similar to those of the 5-year averaged contributions (see the Supplement, Table S3). The differences in the relative contributions from each source to the $\mathrm{BC}$ concentrations between maxima and minima were lower than $12 \%$. For $\mathrm{BC}$ total deposition, the relative contribution from biomass burning in Siberia (SIB-BB) showed variation from 8.2 to $24.0 \%$ (Table S3).

\section{Conclusions}

We investigated the long-range transport of $\mathrm{BC}$ from various source regions and origins to the Arctic and quantified source contributions using a global chemical transport model, GEOS-Chem, with a tagged tracer simulation for 5 years (2007-2011). This study especially focused on the transport pathways from the individual source regions to the Arctic and the role of wet scavenging during long-range transport. For tagging $\mathrm{BC}$, we distinguished $\mathrm{BC}$ tracers by source types (anthropogenic and biomass burning) and regions; the global domain was divided into 16 and 27 regions for anthropogenic and biomass burning emissions, respectively.

We evaluated the simulated BC by comparing it with observations at surface measurement sites in the Arctic and near large source regions in the northern midlatitudes. The vertical profile of modeled BC was also compared with the observations by the ARCTAS aircraft campaign over the Arctic. We introduced a parameterization of BC aging into GEOSChem and changed the wet scavenging ratio by ice clouds $(T<258 \mathrm{~K})$ to examine the sensitivities of these processes to Arctic BC. By using these new schemes, the BC concentrations were increased at the Arctic, especially in winter and spring. Although the new scheme overestimated the observations at Zeppelin and Barrow, especially during winter, model the negative biases in the cold season were improved at Alert and Tiksi. The model also successfully reproduced the observed mean vertical distribution of $\mathrm{BC}$ over the Arctic. Our simulations suggested that there are remaining uncertainties in aging and wet scavenging processes, and measurements are crucial to constrain the model representations of these processes. Further model improvements of key processes, including a microphysics-based parameterization of 
BC aging (Oshima and Koike, 2013; He et al., 2016) and wet scavenging by mixed-phase clouds (Qi et al., 2017a, b), are also important.

We examined detailed transport pathways from the individual source regions to the Arctic and identified important regions where inflow from the individual source regions to the Arctic occurred. Our simulation showed that BC originating from Europe and Russia was transported to the Arctic mainly in the lower troposphere during winter and spring. In particular, BC transported from Russia is extensively distributed over the Arctic in these seasons, leading to the dominant contribution of $62 \%$ to Arctic BC near the surface in the annual mean. We also found that this contribution of $\mathrm{BC}$ from Russia had a key role in the seasonal variation in the Arctic BC at the surface. For the Arctic air pollution near the surface, BC originating from anthropogenic sources in Russia and Europe was important due to its large contributions during the Arctic haze season.

In the middle troposphere, we found a large contribution from East Asia to Arctic BC, which resulted from uplifting during long-range transport. Our simulation demonstrated that BC from East Asia was transported to the Arctic mainly through the Sea of Okhotsk and eastern Siberia during winter and spring. We identified an important region where a strong inflow from East Asia to the Arctic occurred $\left(130-180^{\circ} \mathrm{E}\right.$ and $3-8 \mathrm{~km}$ of altitude at $\left.66^{\circ} \mathrm{N}\right)$. The model simulation showed that the contribution from East Asia to the Arctic had a maximum at about $5 \mathrm{~km}$ of altitude in early spring. The efficiency of transport from East Asia to the Arctic was smaller than that from other large source regions such as Europe, Russia, and North America. However, the contribution of East Asia was the most important to the middle troposphere $(41 \%)$ and BC burden $(27 \%)$ over the Arctic because of large emissions from this region. These results suggest that the main source of Arctic BC differs with altitude.

The total contribution of anthropogenic sources to the BC concentrations at the surface was dominant (about 90\%) compared with that of biomass burning in the annual mean. However, for BC deposition on the Arctic, the contributions of biomass burning emissions from Siberia and Alaska and Canada became substantial during summer and were important, accounting for $15 \%(32 \%)$ and $12 \%$ (31\%) of the annual mean (during summer), respectively.

Data availability. GEOS-Chem used in this study can be downloaded from http://acmg.seas.harvard.edu/geos/.

The Supplement related to this article is available online at https://doi.org/10.5194/acp-17-10515-2017supplement.
Competing interests. The authors declare that they have no conflict of interest.

Special issue statement. This article is part of the special issue "Global and regional assessment of intercontinental transport of air pollution: results from HTAP, AQMEII and MICS". It is not associated with a conference.

Acknowledgements. Measurement data at Arctic and EUSAAR sites were obtained at http://ebas.nilu.no. Data from the IMPROVE network in the US were taken from http://views.cira.colostate.edu/fed. We thank NASA for providing the ARCTAS aircraft campaign data. This research was supported by the Environmental Research and Technology Development Fund (2-1505) from the Ministry of the Environment of Japan, the Coordination Funds for Promoting AeroSpace Utilization by the Ministry of Education, Culture, Sports, Science and Technology (MEXT) of Japan, and JSPS KAKENHI grant number JP26550021. We thank Satoshi Inomata (National Institute for Environmental Studies) for valuable comments and discussions. This work is a contribution to PACES (air Pollution in the Arctic: Climate Environment and Societies), an activity sponsored by the IGAC (International Global Atmospheric Chemistry) project.

Edited by: Gregory Carmichael

Reviewed by: two anonymous referees

\section{References}

AMAP: AMAP Assessment 2015: Black Carbon and Ozone as Arctic Climate Forcers, vii, Arctic Monitoring and Assessment Programme (AMAP), Oslo, Norway, 116 pp., 2015.

Arnold, S. R., Law, K. S., Brock, C. A., Thomas, J. L., Starkweather, S. M., von Salzen. K., Stohl, A., Sharma, S., Lund, M. T., Flanner, M. G., Petäjä, T., Tanimoto, H., Gamble, J., Dibb, J. E., Melamed, M., Johnson, N., Fidel, M., Tynkkynen, V.-P., Baklanov, A., Eckhardt, S., Monks, S. A., Browse, J., and Bozem, H.: Arctic air pollution: challenges and opportunities for the next decade, Elementa: Science of the Anthropocene, 4, 000104, https://doi.org/10.12952/journal.elementa.000104, 2016.

Barrie, L. A.: Arctic air pollution: an overview of current knowledge, Atmos. Environ., 20, 643-663, https://doi.org/10.1016/0004-6981(86)90180-0, 1986.

Bey, I., Jacob, D. J., Logan, J. A., and Yantosca, R. M.: Asian chemical outflow to the Pacific in spring: origins, pathways, and budgets, J. Geophys. Res.-Atmos., 106, 23097-23113, 2001.

Bond, T. C. and Bergstrom, R. W.: Light absorption by carbonaceous particles: an investigative review, Aerosol Sci. Tech., 40, 27-67, https://doi.org/10.1080/02786820500421521, 2006.

Bond, T. C., Bhardwaj, E., Dong, R., Jogani, R., Jung, S. K., Roden, C., Streets, D. G., and Trautmann, N. M.: Historical emissions of black and organic carbon aerosol from energy-related combustion, 1850-2000, Global Biogeochem. Cy., 21, GB2018, https://doi.org/10.1029/2006GB002840, 2007. 
Bourgeois, Q. and Bey, I.: Pollution transport efficiency toward the Arctic: sensitivity to aerosol scavenging and source regions, J. Geophys. Res., 116, D08213, https://doi.org/10.1029/2010JD015096, 2011.

Browse, J., Carslaw, K. S., Arnold, S. R., Pringle, K., and Boucher, O.: The scavenging processes controlling the seasonal cycle in Arctic sulphate and black carbon aerosol, Atmos. Chem. Phys., 12, 6775-6798, https://doi.org/10.5194/acp12-6775-2012, 2012.

Di Pierro, M., Jaeglé, L., and Anderson, T. L.: Satellite observations of aerosol transport from East Asia to the Arctic: three case studies, Atmos. Chem. Phys., 11, 2225-2243, https://doi.org/10.5194/acp-11-2225-2011, 2011.

Eckhardt, S., Quennehen, B., Olivié, D. J. L., Berntsen, T. K., Cherian, R., Christensen, J. H., Collins, W., Crepinsek, S., Daskalakis, N., Flanner, M., Herber, A., Heyes, C., Hodnebrog, Ø., Huang, L., Kanakidou, M., Klimont, Z., Langner, J., Law, K. S., Lund, M. T., Mahmood, R., Massling, A., Myriokefalitakis, S., Nielsen, I. E., Nøjgaard, J. K., Quaas, J., Quinn, P. K., Raut, J.-C., Rumbold, S. T., Schulz, M., Sharma, S., Skeie, R. B., Skov, H., Uttal, T., von Salzen, K., and Stohl, A.: Current model capabilities for simulating black carbon and sulfate concentrations in the Arctic atmosphere: a multi-model evaluation using a comprehensive measurement data set, Atmos. Chem. Phys., 15, 9413-9433, https://doi.org/10.5194/acp15-9413-2015, 2015.

Fisher, J. A., Jacob, D. J., Wang, Q., Bahreini, R., Carouge, C. C., Cubison, M. J., Dibb, J. E., Diehl, T., Jimenez, J. L., Leibensperger, E. M., Lu, Z., Meinders, M. B. J., Pye, H. O. T., Quinn, P. K., Sharma, S., Streets, D. G., van Donkelaar, A., and Yantosca, R. M.: Sources, distribution, and acidity of sulfateammonium aerosol in the Arctic in winter-spring, Atmos. Environ., 45, 7301-7318, https://doi.org/10.1016/j.atmosenv.2011.08.030, 2011

Flanner, M. G.: Arctic climate sensitivity to local black carbon, J. Geophys. Res.-Atmos., 118, 1840-1851, https://doi.org/10.1002/jgrd.50176, 2013.

Flanner, M. G., Zender, C. S., Randerson, J. T., and Rasch, P. J.: Present-day climate forcing and response from black carbon in snow, J. Geophys. Res.-Atmos., 112, D11202, https://doi.org/10.1029/2006JD008003, 2007.

Garrett, T. J. and Zhao, C.: Increased Arctic cloud longwave emissivity associated with pollution from mid-latitudes, Nature, 440, 787-789, 2006.

Garrett, T. J., Brattström, S., Sharma, S., Worthy, D. E. J., and Novelli, P.: The role of scavenging in the seasonal transport of black carbon and sulfate to the Arctic, Geophys. Res. Lett., 38, L16805, https://doi.org/10.1029/2011GL048221, 2011.

Hansen, J. and Nazarenko, L.: Soot climate forcing via snow and ice albedos, P. Natl. Acad. Sci. USA, 101, 423-428, https://doi.org/10.1073/pnas.2237157100, 2004.

He, C., Li, Q., Liou, K.-N., Qi, L., Tao, S., and Schwarz, J. P.: Microphysics-based black carbon aging in a global CTM: constraints from HIPPO observations and implications for global black carbon budget, Atmos. Chem. Phys., 16, 3077-3098, https://doi.org/10.5194/acp-16-3077-2016, 2016.

Hirdman, D., Sodemann, H., Eckhardt, S., Burkhart, J. F., Jefferson, A., Mefford, T., Quinn, P. K., Sharma, S., Ström, J., and Stohl, A.: Source identification of short-lived air pollutants in the Arctic using statistical analysis of measurement data and particle dispersion model output, Atmos. Chem. Phys., 10, 669-693, https://doi.org/10.5194/acp-10-669-2010, 2010.

Huang, L., Gong, S. L., Jia, C. Q., and Lavoue, D.: Importance of deposition processes in simulating the seasonality of the Arctic black carbon aerosol, J. Geophys. Res.-Atmos., 115, D17207, https://doi.org/10.1029/2009JD013478, 2010.

Huang, K., Fu, S. J., Prikhodko, Y. V., Storey, M. J., Romanov, A., Hodson, L. E., Cresko, J., Morozova, I., Ignatieva, Y., and Cabaniss, J.: Russian anthropogenic black carbon: emission reconstruction and Arctic black carbon simulation, J. Geophys. Res.-Atmos., 120, 11306-11333, https://doi.org/10.1002/2015JD023358, 2015.

Janssens-Maenhout, G., Crippa, M., Guizzardi, D., Dentener, F., Muntean, M., Pouliot, G., Keating, T., Zhang, Q., Kurokawa, J., Wankmüller, R., Denier van der Gon, H., Kuenen, J. J. P., Klimont, Z., Frost, G., Darras, S., Koffi, B., and Li, M.: HTAP_v2.2: a mosaic of regional and global emission grid maps for 2008 and 2010 to study hemispheric transport of air pollution, Atmos. Chem. Phys., 15, 11411-11432, https://doi.org/10.5194/acp-15-11411-2015, 2015.

Kanaya, Y., Pan, X., Miyakawa, T., Komazaki, Y., Taketani, F., Uno, I., and Kondo, Y.: Long-term observations of black carbon mass concentrations at Fukue Island, western Japan, during 2009-2015: constraining wet removal rates and emission strengths from East Asia, Atmos. Chem. Phys., 16, 1068910705, https://doi.org/10.5194/acp-16-10689-2016, 2016.

Klonecki, A., Hess, P., Emmons, L., Smith, L., Orlando, J., and Blake, D.: Seasonal changes in the transport of pollutants into the Arctic troposphere-model study, J. Geophys. Res., 108, 8367, https://doi.org/10.1029/2002JD002199, 2003.

Koch, D. and Hansen, J.: Distant origins of Arctic black carbon: a Goddard Institute for Space Studies ModelE experiment, J. Geophys. Res.-Atmos., 110, D04204, https://doi.org/10.1029/2004JD005296, 2005.

Koch, D., Schulz, M., Kinne, S., McNaughton, C., Spackman, J. R., Balkanski, Y., Bauer, S., Berntsen, T., Bond, T. C., Boucher, O., Chin, M., Clarke, A., De Luca, N., Dentener, F., Diehl, T., Dubovik, O., Easter, R., Fahey, D. W., Feichter, J., Fillmore, D., Freitag, S., Ghan, S., Ginoux, P., Gong, S., Horowitz, L., Iversen, T., Kirkevåg, A., Klimont, Z., Kondo, Y., Krol, M., Liu, X., Miller, R., Montanaro, V., Moteki, N., Myhre, G., Penner, J. E., Perlwitz, J., Pitari, G., Reddy, S., Sahu, L., Sakamoto, H., Schuster, G., Schwarz, J. P., Seland, Ø., Stier, P., Takegawa, N., Takemura, T., Textor, C., van Aardenne, J. A., and Zhao, Y.: Evaluation of black carbon estimations in global aerosol models, Atmos. Chem. Phys., 9, 9001-9026, https://doi.org/10.5194/acp-9-9001-2009, 2009.

Law, K. S. and Stohl, A.: Arctic air pollution: origins and impacts, Science, 315, 1537-1540, https://doi.org/10.1126/science.1137695, 2007.

Lee, Y. H., Lamarque, J.-F., Flanner, M. G., Jiao, C., Shindell, D. T., Berntsen, T., Bisiaux, M. M., Cao, J., Collins, W. J., Curran, M., Edwards, R., Faluvegi, G., Ghan, S., Horowitz, L. W., McConnell, J. R., Ming, J., Myhre, G., Nagashima, T., Naik, V., Rumbold, S. T., Skeie, R. B., Sudo, K., Takemura, T., Thevenon, F., Xu, B., and Yoon, J.-H.: Evaluation of preindustrial to present-day black carbon and its albedo forcing from Atmospheric Chemistry and Climate Model Intercompar- 
ison Project (ACCMIP), Atmos. Chem. Phys., 13, 2607-2634, https://doi.org/10.5194/acp-13-2607-2013, 2013.

Liu, H. Y., Jacob, D. J., Bey, I., and Yantosca, R. M.: Constraints from $\mathrm{Pb}-210$ and $\mathrm{Be}-7$ on wet deposition and transport in a global three-dimensional chemical tracer model driven by assimilated meteorological fields, J. Geophys. Res.-Atmos., 106, 1210912128, 2001.

Liu, J., Fan, S., Horowitz, L. W., and Levy II, H.: Evaluation of factors controlling long-range transport of black carbon to the Arctic, J. Geophys. Res., 116, D00A14, https://doi.org/10.1029/2010JD015145, 2011.

Lubin, D. and Vogelmann, A. M.: A climatologically significant aerosol longwave indirect effect in the arctic, Nature, 439, 453456, 2006

Lund, M. T. and Berntsen, T.: Parameterization of black carbon aging in the OsloCTM2 and implications for regional transport to the Arctic, Atmos. Chem. Phys., 12, 6999-7014, https://doi.org/10.5194/acp-12-6999-2012, 2012.

Mahmood, R., von Salzen, K., Flanner, M., Sand, M., Langner, J., Wang, H., and Huang, L.: Seasonality of global and Arctic black carbon processes in the Arctic Monitoring and Assessment Programme models, J. Geophys. Res.-Atmos., 121, 7100-7116, https://doi.org/10.1002/2016JD024849, 2016.

Matsui, H., Kondo, Y., Moteki, N., Takegawa, N., Sahu, L. K., Zhao, Y., Fuelberg, H. E., Sessions, W. R., Diskin, G., Blake, D. R., Wisthaler, A., and Koike, M.: Seasonal variation of the transport of black carbon aerosol from the Asian continent to the Arctic during the ARCTAS aircraft campaign, J. Geophys. Res.-Atmos., 116, D05202, https://doi.org/10.1029/2010JD015067, 2011.

Oshima, N. and Koike, M.: Development of a parameterization of black carbon aging for use in general circulation models, Geosci. Model Dev., 6, 263-282, https://doi.org/10.5194/gmd-6263-2013, 2013.

Park, R. J., Jacob, D. J., Palmer, P. I., Clarke, A. D., Weber, R. J., Zondlo, M. A., Eisele, F. L., Bandy, A. R., Thornton, D. C., Sachse, G. W., and Bond, T. C.: Export efficiency of black carbon aerosol in continental outflow: global implications, J. Geophys. Res.-Atmos., 110, D11205, https://doi.org/10.1029/2004JD005432, 2005.

Qi, L., Li, Q., Li, Y., and He, C.: Factors controlling black carbon distribution in the Arctic, Atmos. Chem. Phys., 17, 1037-1059, https://doi.org/10.5194/acp-17-1037-2017, 2017a.

Qi, L., Li, Q., He, C., Wang, X., and Huang, J.: Effects of the Wegener-Bergeron-Findeisen process on global black carbon distribution, Atmos. Chem. Phys., 17, 7459-7479, https://doi.org/10.5194/acp-17-7459-2017, $2017 \mathrm{~b}$.

Qi, L., Li, Q., Henze, D. K., Tseng, H.-L., and He, C.: Sources of springtime surface black carbon in the Arctic: an adjoint analysis, Atmos. Chem. Phys., 17, 9697-9716, https://doi.org/10.5194/acp-17-9697-2017, 2017c.

Quinn, P. K., Shaw, G., Andrews, E., Dutton, E. G., Ruoho-Airola, T., and Gong, S. L.: Arctic haze: current trends and knowledge gaps, Tellus B, 59, 99-114, https://doi.org/10.1111/j.1600-0889.2006.00238.x, 2007.

Quinn, P. K., Bates, T. S., Baum, E., Doubleday, N., Fiore, A. M., Flanner, M., Fridlind, A., Garrett, T. J., Koch, D., Menon, S., Shindell, D., Stohl, A., and Warren, S. G.: Short-lived pollutants in the Arctic: their climate impact and possible mitigation strategies, Atmos. Chem. Phys., 8, 1723-1735, https://doi.org/10.5194/acp-8-1723-2008, 2008.

Sand, M., Berntsen, T. K., von Salzen, K., Flanner, M. G., Langner, J., and Victor, D. G.: Response of Arctic temperature to changes in emissions of short-lived climate forcers, Nat. Clim. Change, 6, 286-289, https://doi.org/10.1038/nclimate2880, 2016.

Sharma, S., Ishizawa, M., Chan, D., Lavoue, D., Andrews, E., Eleftheriadis, K., and Maksyutov, S.: 16 year simulation of Arctic black carbon: transport, source contribution, and sensitivity analysis on deposition, J. Geophys. Res.-Atmos., 118, 943-964, https://doi.org/10.1029/2012jd017774, 2013.

Shindell, D.: Local and remote contributions to Arctic warming, Geophys. Res. Lett., 34, L14704, https://doi.org/10.1029/2007GL030221, 2007.

Shindell, D. and Faluvegi, G.: Climate response to regional radiative forcing during the twentieth century, Nat. Geosci., 2, 294-300, https://doi.org/10.1038/ngeo473, 2009.

Shindell, D. T., Chin, M., Dentener, F., Doherty, R. M., Faluvegi, G., Fiore, A. M., Hess, P., Koch, D. M., MacKenzie, I. A., Sanderson, M. G., Schultz, M. G., Schulz, M., Stevenson, D. S., Teich, H., Textor, C.,Wild, O., Bergmann, D. J., Bey, I., Bian, H., Cuvelier, C., Duncan, B. N., Folberth, G., Horowitz, L. W., Jonson, J., Kaminski, J. W., Marmer, E., Park, R., Pringle, K. J., Schroeder, S., Szopa, S., Takemura, T., Zeng, G., Keating, T. J., and Zuber, A.: A multi-model assessment of pollution transport to the Arctic, Atmos. Chem. Phys., 8, 5353-5372, https://doi.org/10.5194/acp-8-5353-2008, 2008.

Stohl, A.: Characteristics of atmospheric transport into the Arctic troposphere, J. Geophys. Res.-Atmos., 111, D11306, https://doi.org/10.1029/2005JD006888, 2006.

Stohl, A., Andrews, E., Burkhart, J. F., Forster, C., Herber, A., Hoch, S. W., Kowal, D., Lunder, C., Mefford, T., Ogren, J. A., Sharma, S., Spichtinger, N., Stebel, K., Stone, R., Ström, J., Tørseth, Wehrli, C., and Yttri, K. E.: Pan-Arctic enhancements of light absorbing aerosol concentrations due to North American boreal forest fires during summer 2004, J. Geophys. Res., 111, D22214, https://doi.org/10.1029/2006JD007216, 2006.

Stohl, A., Berg, T., Burkhart, J. F., Fjæraa, A. M., Forster, C., Herber, A., Hov, Ø., Lunder, C., McMillan, W. W., Oltmans, S., Shiobara, M., Simpson, D., Solberg, S., Stebel, K., Störm, J., Tørseth, K., Treffeisen, R., Virkkunen, K., and Yttri, K. E.: Arctic smoke - record high air pollution levels in the European Arctic due to agricultural fires in Eastern Europe in spring 2006, Atmos. Chem. Phys., 7, 511-534, https://doi.org/10.5194/acp-7511-2007, 2007.

Stohl, A., Klimont, Z., Eckhardt, S., Kupiainen, K., Shevchenko, V. P., Kopeikin, V. M., and Novigatsky, A. N.: Black carbon in the Arctic: the underestimated role of gas flaring and residential combustion emissions, Atmos. Chem. Phys., 13, 8833-8855, https://doi.org/10.5194/acp-13-8833-2013, 2013.

Stocks, B., Fosberg, M., Lynham, T., Mearns, L., Wotton, B., Yang, Q., Jin, J., Lawrence, K., Hartley, G., Mason, J., and McKenney, D.: Climate change and forest fire potential in Russian and Canadian boreal forests, Climate Change, 38, 1-13, 1998.

van der Werf, G. R., Randerson, J. T., Giglio, L., Collatz, G. J., Mu, M., Kasibhatla, P. S., Morton, D. C., DeFries, R. S., Jin, Y., and van Leeuwen, T. T.: Global fire emissions and the 
contribution of deforestation, savanna, forest, agricultural, and peat fires (1997-2009), Atmos. Chem. Phys., 10, 11707-11735, https://doi.org/10.5194/acp-10-11707-2010, 2010.

Wang, Y. H., Jacob, D. J., and Logan, J. A.: Global simulation of tropospheric $\mathrm{O}_{3}-\mathrm{NO}_{x}$-hydrocarbon chemistry 1 . model formulation, J. Geophys. Res.-Atmos., 103, 10713-10725, 1998.

Wang, Q., Jacob, D. J., Fisher, J. A., Mao, J., Leibensperger, E. M., Carouge, C. C., Le Sager, P., Kondo, Y., Jimenez, J. L., Cubison, M. J., and Doherty, S. J.: Sources of carbonaceous aerosols and deposited black carbon in the Arctic in winter-spring: implications for radiative forcing, Atmos. Chem. Phys., 11, 1245312473, https://doi.org/10.5194/acp-11-12453-2011, 2011.

Wang, H. L., Rasch, P. J., Easter, R. C., Singh, B., Zhang, R. D., Ma, P. L., Qian, Y., Ghan, S. J., and Beagley, N.: Using an explicit emission tagging method in global modeling of source-receptor relationships for black carbon in the Arctic: variations, sources, and transport pathways, J. Geophys. Res.-Atmos., 119, 1288812909, https://doi.org/10.1002/2014jd022297, 2014.
Warneke, C., Froyd, K. D., Brioude, J., Bahreini, R., Brock, C. A., Cozic, J., de Gouw, J. A., Fahey, D. W., Ferrare, R., Holloway, J. S., Middlebrook, A. M., Miller, L., Montzka, S., Schwarz, J. P., Sodemann, H., Spackman, J. R., and Stohl, A.: An important contribution to springtime Arctic aerosol from biomass burning in Russia, Geophys. Res. Lett., 37, L01801, https://doi.org/10.1029/2009GL041816, 2010.

Zhang, X. Y., Wang, Y. Q., Niu, T., Zhang, X. C., Gong, S. L., Zhang, Y. M., and Sun, J. Y.: Atmospheric aerosol compositions in China: spatial/temporal variability, chemical signature, regional haze distribution and comparisons with global aerosols, Atmos. Chem. Phys., 12, 779-799, https://doi.org/10.5194/acp12-779-2012, 2012 